Review

\title{
Sustainable and Renewable Energy: An Overview of the Application of Multiple Criteria Decision Making Techniques and Approaches
}

\author{
Abbas Mardani ${ }^{1, *}$, Ahmad Jusoh ${ }^{1}$, Edmundas Kazimieras Zavadskas ${ }^{2}$, Fausto Cavallaro ${ }^{3}$ \\ and Zainab Khalifah ${ }^{1}$ \\ 1 Faculty of Management, Universiti Teknologi Malaysia (UTM), Skudai Johor 81310, Malaysia; \\ E-Mails: ahmadj@management.utm.my (A.J.); zainab@management.utm.my (Z.K.) \\ 2 Department of Construction Technology and Management, Vilnius Gediminas Technical \\ University, Sauletekio al. 11, Vilnius LT-10223, Lithuania; E-Mail: edmundas.Zavadskas@vgtu.lt \\ 3 Department of Economics, Management, Society and Institutions (EGSI), University of Molise, \\ Via De Sanctis, Campobasso 86100, Italy; E-Mail: cavallaro@unimol.it \\ * Author to whom correspondence should be addressed; E-Mail: mabbas3@live.utm.my; \\ Tel.: +60-112-734-7432; Fax: +60-12-766-6097.
}

Academic Editor: Vincenzo Torretta

Received: 2 September 2015 / Accepted: 30 September 2015 / Published: 19 October 2015

\begin{abstract}
The main purpose of this paper is to present a systematic review of MCDM techniques and approaches in sustainable and renewable energy systems problems. This study reviewed a total of 54 papers published from 2003-2015 in more than 20 high-ranking journals, most related to sustainable and renewable energies, and which were extracted from the Web of Science database. In the category of application areas, papers were classified into two main groups: (1) sustainable energy and (2) renewable energy. Furthermore, in the classification of techniques and approaches, the papers were categorized into six groups: (1) AHP and F-AHP; (2) ANP and VIKOR; (3) TOPSIS and F-TOPSIS; (4) PROMETHEE; (5) integrated methods and (6) other methods. In addition, papers were reviewed based on the authors' nationalities, the publication date, techniques and approaches, the name of journal and studies criteria. The results of this study indicated that, in 2015, scholars have published more papers than in other years. Furthermore, AHP/fuzzy AHP and integrated methods were ranked as the first rank, with 14 papers. Additionally, Journal of Renewable Energy is the first journal, with 16 publications, and this was the most significant journal in this study. Findings of this review paper confirm
\end{abstract}


that MCDM techniques can assist stakeholders and decision makers in unravelling some of the uncertainties inherent in environmental decision making, and these techniques demonstrate a growing interest of previous scholars to apply these techniques for solving different stages of sustainable and renewable energy systems.

Keywords: decision making; environmental systems; MCDM; renewable energy; sustainable energy

\section{Introduction}

Over the last quarter-century, the twin concepts of sustainability and renewable energy have emerged as a defining imperative of humanity that is situated at the nexus of science $[1,2]$, technology $[3,4]$, culture $[5,6]$, economics $[7,8]$, policy $[9,10]$ and the environment $[11,12]$. These twin concepts are both framed as a means to mitigate the negative impacts of natural resource depletion [13,14], energy consumption [13-17], water consumption [18,19] and climate changing greenhouse gas (GHG) emissions [20-22] associated anthropogenic activities. Due to the energy crisis, environmental, economic, political, market and social issues, researchers have been attracted to develop sources of sustainable and renewable energies to secure energy consumption, protect the environment, and to promote regional development. The implementation of successful renewable energy that is sustainable in time, especially at the community level, has been related to more open and participatory processes where views, expectations and framings from different stakeholders become integrated. In the issues of sustainability and renewable energy, various methodologies can be found throughout the literature. Some of them are scenario planning, which seeks to address and put limits on uncertainty, improving the response capacity to multiple features [23]. Kowalski, et al. [24], using a combination of scenario planning and Multi Criteria Assessment (MCA) to reduce uncertainty in energy development, where a diversity of stakeholders is included in the decision-making process, considering a broad spectrum of social, economic, environmental and technical criteria.

On the other hand, strong emphasis is put on renewable energy as sustainable technologies, focusing on the relation of renewable energy projects with the overall sustainability of a particular community or system [25]. It is usually stated that renewable energy contributes to the sustainability of specific territories by providing them with a wide variety of socioeconomic and environmental benefits [26]. These assessments focus on specific components of sustainability (ecological, social and economic) through the monitoring of indicators, with few cases giving attention to the dynamic component of sustainability. Sustainability is a system issue, not a technology or organizational issue [27], yet in renewable energy literature it is rarely addressed as such. Bringing insights from sustainability science and socio-ecological systems theory, in analyzing the sustainability of an energy system, strong emphasis is put on the importance of understanding the complexity of the system, adaptative management and adaptative capacity in the successful adoption of renewable energy technologies [28]. Due to the complexity of sustainability and the need to provide a path towards the achievement of a sustainable future, decisions have to be taken, and this must happen in a structured, transparent and reliable way and multiple criteria decision making (MCDM) can contribute to such an objective. The 
energy issues applying decision making (DM) methods include energy planning and selection [29], energy resource allocation [30,31], energy exploitation [32], energy policy [33], management of building energy [34] and transportation of energy systems [35,36]. The reviewed literatures covered are both theoretical/conceptual and empirical. This review article aims at providing an overview of a number of major MCDM approaches and techniques proposed over the years and presenting examples of the ways various approaches and techniques have been used for sustainable and renewable energy issues. The examples were selected in a way to give an extensive overview of all approaches and techniques applied to environmental sustainable and renewable energy issues during recent years. This paper also evaluates the most important advantages of various approaches and techniques, and the difficulties that they may face. Finally, this study argues that MCDM is practical for solving problems in sustainable and renewable energy issues with multiple resources; although some previous studies reviewed the role of MCDM methods such as multiple criteria decision making analysis (MCDA) in sustainable energy [37] and sustainable energy planning [38], this type of problem has been insufficiently examined in MCDM review studies.

\section{Literature Review}

\section{Role of Decision Making Techniques and Approaches in Sustainable and Renewable Energy}

The availability of renewable energy sources is growing rapidly in many developed and developing countries [39-41]. Growth in two common renewable energy sources-wind and solar photovoltaics (PV) [42-44] has been significant in recent years. Moreover, these high growth rates are expected to continue for renewable technologies for several years to come, if one believes the flurry of optimistic estimates by industry groups and energy analysts. The basic premise of all renewable energy development policies is that they create demand for climate-friendly technologies that otherwise would not exist at all or not at desired levels under current market conditions [45]. An integrated renewable energy system includes renewable energy generation [46-50], energy storage [51-56] and certain transmission components [57-59]. A renewable energy system could have a life-cycle efficiency of less than $100 \%$ and still be superior to a fossil based system in terms of energy resources sustainability. The use of modern renewable energy technologies, including wind turbines [60-62], solar panels [42,63], biomass pellets [64,65], small hydro [66-68] and others are increasing rapidly. Renewable energy might solve some of the existing problems. The research and development of a renewable energy plan is imperative to fuel the transportation fleets of the future and to promote the new energy economy. As the number of new renewable energy policies at the state level has increased, so have policy analyses and evaluations focusing on individual programs [69-72]. Previous research on alternative and renewable energy is commonly based on cross-country data, employs panel econometric models with fixed or dynamic effects (e.g., $[73,74])$ and predominantly examines the drivers of renewable energy where it is used as a dependent variable (e.g., [75]).

In recent years, due to increasing energy demand, the use of renewable energy technologies has grown dramatically, therefore some of the previous studies have investigated the role of these technologies in different perspectives of energy issues with various techniques of MCDM. For example: Luthra, et al. [76] identified the barriers for adoption of renewable and sustainable 
technologies in India by using the analytic hierarchy process (AHP) technique; Streimikiene, et al. [77], ranked and selected some sustainable electricity production technologies by integration of Technique for Order of Preference by Similarity to Ideal Solution (TOPSIS) and MOORA plus Full Multiplicative form (MULTIMOORA) techniques; van de Kaa, et al. [78] used the fuzzy MCDM method, fuzzy AHP, for choosing the photovoltaic technologies; Shen, et al. [79], with concerns of policy and technology, evaluated renewable energy resources exploiting by application of fuzzy AHP; Zhao and Guo [80] applied superiority linguistic ratings, fuzzy grey relation analysis and the entropy weighting method for assessment of the external benefits of renewable energy power in China; Zhao and Guo [81] also integrated fuzzy entropy and TOPSIS for choosing a thermal power equipment supplier; Stein [82] proposed a novel approach for ranking of several renewable and non-renewable technologies related to electricity production; Doukas, et al. [83] presented flexible and direct MCDM methods though linguistic variables for ranking of sustainable technological energy; Balezentiene, et al. [84] used fuzzy MULTIMOORA for ranking of sustainable energy crops; Oberschmidt, et al. [85] elaborated the Preference Ranking Organisation Method for Enrichment Evaluations (PROMETHEE) technique for evaluation of performance in energy supply technologies and applied the AHP technique for electricity generation based on some renewable energy alternatives such as solar photovoltaic, wind energy, biomass and solar thermal in Pakistan; Zangeneh, et al. [86] proposed a model for evaluation and ranking of distributed technologies in Iran; Ren, et al. [87] employed fuzzy MCDM (FMCDM) for assessment and ranking sustainability of biomass-based hydrogen technologies; and Troldborg, et al. [88] proposed a multi criteria analysis for evaluation and ranking of renewable energy technologies in Scotland.

In addition, due to diversification opportunities, biomass production has the potential to enhance the feasibility of agricultural business [84]. For example, in the Czech Republic, Havličková and Suchý [89] made an analysis on the future prospects of energy crop propagation. Using data envelopment analysis, Đatkov and Effenberger [90] investigated the efficiency of biogas plants, nevertheless problems regarding energy planning are very complex with multiple criteria and multiple decision makers (DMs). As a result, these problems are suited to the application of MCDM. The MCDM approaches and techniques are often applied to assess and compare the sustainability of different renewable energy technologies or energy plans with the aim to provide decision support for choosing the most sustainable and suitable options either for a given location or more generically. MCDM is attractive given the multi-dimensional and complex nature of sustainability assessments, which typically involve a range of conflicting criteria featuring different forms of data and information. However, the input information on which the MCDM is based is often associated with uncertainties. When evaluating the sustainability of different renewable energy generation technologies, there is a range of important indicators and criteria that need to be considered [91]. It has been widely applied for assessing and comparing the sustainability of different renewable energy technologies, plans and policies [37], both in specific areas or regions (e.g., [92-95]), and for more generic assessments (e.g., [77,96]).

Although there have been many empirical studies of the application of MCDM in environmental decision making, studies on how uncertainty analysis in MCDM can deal with potential uncertainties at each stage of this decision-making procedure are rare. Due to the complexity of environmental systems and the need to provide a path towards the achievement of a future, decisions have to be taken, and this must happen in a structured, transparent and reliable way; MCDM can contribute to such an 
objective. MCDM consists of a group of approaches, which allow explicit accounting of multiple criteria in order to support individuals or groups to rank, select and/or compare different alternatives [97]. A general grouping of MCDM approaches has been proposed by [98], who distinguish three underlying theories: (i) utility function; (ii) outranking relation and (iii) sets of decision rules. The utility-based theory includes methods synthesizing the information according to a unique parameter; this theory was introduced in the 1970s by [99]. The outranking relation theory involves methods based on comparisons between pairs of options to verify whether "alternative a is at least as good as alternative b" [100]. The decision rule theory originates from the artificial intelligence domain, and it permits deriving a preference model through the use of classification or comparison of decision examples [101]. MCDM has been used extensively to evaluate environmental systems problems, and a good overview can be found in [102].

Typical environmental assessment methods such as environmental impact assessment [103], social impact assessment [104], risk assessment [105] and life-cycle assessment [106] are generally carried out for one client or one interested party to assist decision-making for sustainable or greener practices. For example, in community development, sustainable planning promotes the integration of programs, which requires the commitment of a number of stakeholders in different disciplines [107].

Over the years, numerous MCDM and FMCDM techniques and approaches have been proposed in the literature, which differ in terms of the type of questions asked, the theoretical background and the type of obtained results. A number of methods have been designed for a particular problem, hence they are inapplicable to other problems. Recently, a number of MCDM and FMCDM techniques and approaches have been introduced to choose the best compromise options. The MCDM and FMCDM techniques and approaches have been developed not only by the motivation received from various real-life problems that require the consideration of multiple criteria, but also by the desire of practitioners to enhance decision-making techniques through recent developments occurring in computer technology, scientific computing and mathematical optimization [108]. All methods are mainly aimed at making the decision-making process better informed and more formalized. The MCDM approach falls into two categories [109]: classical MCDM and fuzzy FMCDM [110,111].

MCDM problems each have a different nature; thus, a variety of techniques have been proposed as solutions. First, complete aggregation methods were proposed, for example: Simple Additive Weighting (SAW) and two stages in weighting [112]; Multi-attribute utility analysis (MAUA) [113]; Weighted Aggregated Sum Product Assessment (WASPAS) [114]; TOPSIS [115]; VlseKriterijuska Optimizacija I Komoromisno Resenje (VIKOR) [116]; multi-criteria Complex Proportional Assessment method (COPRAS) [117]; Multi-Objective Optimization by Ratio analysis (MOORA) [118]; COPRAS Grey (COPRAS-G), fuzzy additive ratio assessment method (ARAS-F), Grey Additive Ratio Assessment (ARAS-G) and MULTIMOORA [119-121]; KEmeny Median Indicator Ranks Accordance (KEMIRA) [122]; Step-wise Weight Assessment Ratio Analysis (SWARA) [123] and additive ratio assessment method (ARAS) [124,125]. As examples of partial aggregation methods, PROMETHEE [126], ELimination and Choice Expressing REality (ELECTRE) [127] and Novel Approach to Imprecise Assessment and Decision Environments (NAIADE) [128] can be listed, which involve the pair-wise comparisons of alternatives. In addition, Analytic Network Process (ANP) and AHP are relied on as pair-wise comparisons [129-132]. 
FMCDM can be categorized as a fuzzy multi-objective decision-making (FMODM) and fuzzy multi-attribute decision-making (FMADM) approach [109]. Liou and Tzeng [133], addressed the development of MADM from 1738-2012. They put MADM into three classes: evaluating or choosing models (e.g., decision-making trial and evaluation laboratory (DEMATEL), fuzzy DEMATEL, Interpretive Structural Modelling (ISM), fuzzy ISM, fuzzy cognitive map (FCM), linear structure equation models (LISEM, or called "SEM"), formal concept analysis and input-output analysis); weighting models (ANP/fuzzy ANP, AHP/fuzzy AHP, entropy measure, neural network weighting and dynamic weighting) and normalizing models (additive types: TOPSIS, SAW, VIKOR, ELECTRE, PROMETHEE and grey relation and non-additive types: fuzzy integral neural network plus fuzzy). In another classification related to MCDM tools and approaches, Turskis and Zavadskas [134] and Mardani, et al. [135] grouped MCDM and FMCDM tools in a different way-in two of these studies, MCDM was divided into three types: information of actors, including no information (dominance, Maxmin and Minmax classes); information about criteria (standard level (conjunctive and Disjunctive), ordinal (lexicographic, elimination by aspects and permutation), cardinal (liner assignment, SAW, TOPSIS, ELECTRE, PROMETHEE, VIKOR, COPRAS, ARAS and MOORA) and marginal rate of substitution (hierarchical trade-offs)); and information of alternative (pairwise preference (The linear programming technique for multidimensional analysis of preference (LINMAP) and SAW) and order of pairwise proximity (multidimensional scaling)).

The objective of FMADM is finite and implicit, whereas the objective of the FMODM approach is infinite and explicit. In FMADM, the decision maker's objectives are unified under the decision-makers' utility which is a super function, which is dependent upon the selection criteria. In FMODM, objectives of the decision-makers, e.g., optimal resource utilization and quality, improvement remain explicit and are assigned with fuzzy weights that reflect their relative significance. The most important benefit of FMCDM models is their capability of considering many selection criteria. Bellman and Zadeh [136] and Zimmermann [137] applied fuzzy sets to the MCDM field. According to Yager [138], the fuzzy set of a decision is the intersection of the whole fuzzy goals. Kickert [139], prepared a summary of applications of the fuzzy set theory to MADM problems.

MCDM methods cover a wide range of quite distinct approaches. MCDM methods can be broadly classified into two categories: discrete MCDM or discrete MADM and continuous MODM methods [140]. Recently, hundreds of publications have been published to provide information about MCDM methods and their development and application in different fields. This article provides an overview of the publications, which provides an overview of MCDM methods. The research is based on the Web of Science database, which is a part of Thomson Reuters Web of Knowledge. The 1970s was an important decade for many seminal works. Foundations of modern MCDM were developed in the 1950s and 1960s. Development of MCDM researches accelerated during the 80s and early 90s, and seems to have continued its exponential growth [141]. The book by Köksalan, Wallenius and Zionts [141] provided a brief history of the development of MCDM methods. It briefly describes the development of the area from ancient to modern times. Keeney, et al. [142] formulated the basics of decision with multiple objectives. Hwang, et al. [143] provided the review on development of MODM methods and applications in a relatively short period of time. Later, Tzeng and Huang [144] reviewed the MADM methods (SAW, TOPSIS, ELECTRE and LINMAP). 


\section{Research Methodology}

This paper reviews the literature in order to identify the studies that have been published in popular journals that provided the most important information to practitioners and researchers who investigate issues related to sustainable and renewable energy systems and MCDM and FMCDM techniques and approaches. To this end, an extensive search was carried out to find MCDM and FMCDM in titles, abstracts, keywords and research methodologies of the papers. This paper attempts to document the exponentially growing interest in the MCDM and FMCDM techniques and approaches and provide a contemporary and up-to-date review of the literature regarding sustainable and renewable energy systems, MCDM applications and methodologies. According to a classification scheme, a reference repository, including a total of 54 published papers in more than 30 journals since 2003, has been established. The papers are classified in terms of the application areas, publication year, the journal's name and MCDM techniques and approaches and research criteria. The present paper has three contributions: the development of a classification scheme with a focus on practical considerations; structurally reviewing the literature to guide the research on sustainable and renewable energy systems, MCDM applications and methodologies; and the identification of issues to be studied in the future. Additionally, new perspective is taken into consideration to review the articles, namely, categorization of the articles into two different areas including sustainable and renewable energy systems.

In particular, we targeted Web of Science, which includes the most important journals in two different areas: sustainable and renewable energy systems. Items such as doctoral dissertations, master's theses, textbooks, papers and unpublished papers were ignored in this review. For this review, the primary data were collected from 54 cited articles related to sustainable and renewable energy systems since 2003. In the process of choosing the 54 scholarly journal papers, we used most international journals specifically related to sustainable and renewable energy and MCDM issues. Some of the journals cited in this review were, Renewable Energy, Energy Policy, Applied Energy, Energy Conversion and Management, Energy journal, Journal of Environmental Management, Renewable and Sustainable Energy Reviews, Solar Energy, European Journal of Operational Research, Applied Soft Computing, Expert Systems with Applications, Journal of Cleaner Production, Energy and Buildings, etc. The majority of papers on sustainable and renewable energy systems, MCDM applications and methodologies were published after 2003; as a result, we attempted to review application of these techniques in recent years; therefore, this year was chosen as the starting date for this study. It is noticeable that since the online database access point is limited, some papers could not be downloaded; for that reason, they were overlooked in this survey. After reviewing each paper, the paper was summarized and highlighted. An article is taken into consideration in this review if it discusses thoroughly the application and development of MCDM for solving problems in sustainability and renewable energy systems issues. 
MCDM is the most well-known branch of decision making. In the decision-making approach, the selection is made from among the decision alternatives that are described by their attributes. Over time, a large number of MCDM techniques and approaches have been proposed, which are different in their theoretical background, the type of questions asked and the type of obtained results. For a given problem, a number of methods have been particularly proposed, which cannot be applied to other problems. Several keywords and criteria should be taken into account for the selection of the MCDM techniques and approaches. In this review paper, for identifying and finding the scholarly papers related to sustainable and renewable energy systems issues, for MCDM techniques and approaches in Web of Science database, we searched the keywords such as: sustainable energy, wind and solar energies, PV energy, renewable energies, MCA, MCDA, MCDM, decision making, AHP, COPRAS, TOPSIS, VIKOR, ELECTRE, MULTIMOORA, DEMATEL, SWARA, ANP, MOORA, PROMETHEE, WASPAS, SAW, ARAS, Entropy and hybrid MCDM, in addition, in terms of fuzzy MCDM methods.

In the past several years, application of the MCDM technique in energy topics, renewable and sustainable energies increased dramatically. The historical growth rate of MCDM techniques in renewable energy and sustainable energy has been available for many years. This review paper represents the growth dynamics of the papers included in Thomson Reuters Web of Science database under the keywords MCDM and energy (Figure 1), MCDM and renewable energy (Figure 2), MCDM and sustainable energy (Figure 3 ) in recent years.

Figure 1 shows important evidence based on the frequency of the growth dynamics of the papers included in Thomson Reuters Web of Science database under the keywords of MCDM and energy from 2003-2015. The results indicate that from 2003-2015 information about the use of MCDM techniques in energy areas has grown. According to the findings from this figure, the use of these techniques and approaches in 2003 were found in two papers, and this number increased to six papers in 2004; the number of publications increased to 17 and 26 papers in 2012 and 2013, respectively. Accordingly, it can be pointed out that researchers in different fields and categories of energy use MCDM techniques nowadays in their research, and it can be predicted that in coming years, these numbers will increase. Results of publication years are shown in Figure 1.

Figure 2 presents important evidence based on the frequency of the growth dynamics of the papers included in Thomson Reuters Web of Science database under the keywords of MCDM and renewable energy from 2004-2015. The outcomes show that from 2004-2015 information about the use of MCDM techniques in renewable energy areas has grown. According to the findings from this figure, the use of these techniques in 2004 was found in two papers, and this number increased to 10 papers in 2013; the number of publications increased to four and 10 papers in 2012 and 2013, respectively. Accordingly, it indicates that researchers in the field of renewable energy utilize MCDM techniques nowadays in their research, and it can be predicted that in coming years these numbers will increase. Results of publication years are shown in Figure 2. 


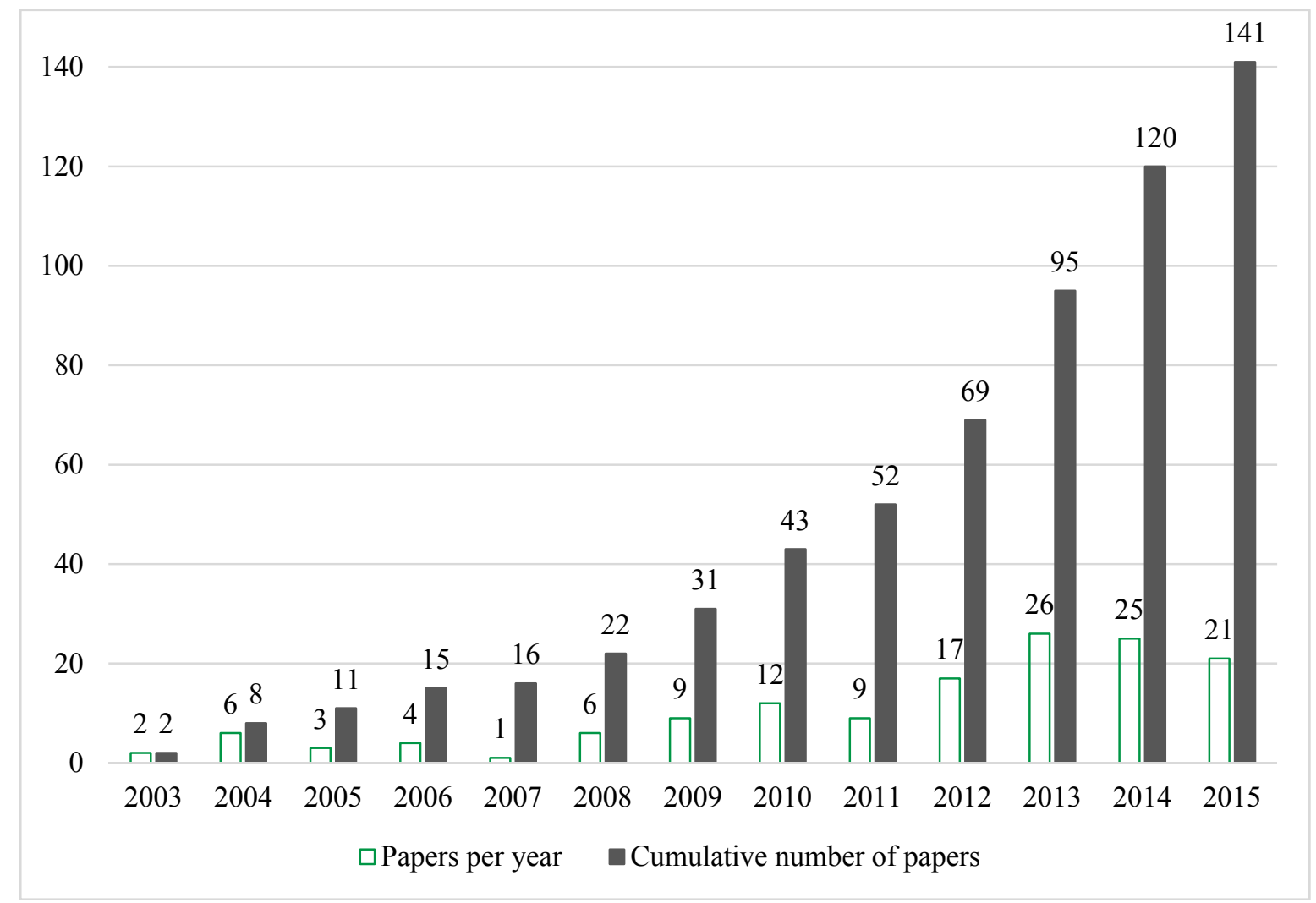

Figure 1. The growth dynamics of the papers included in Thomson Reuters Web of Science Database under the keywords of MCDM and energy from 2003-2015.

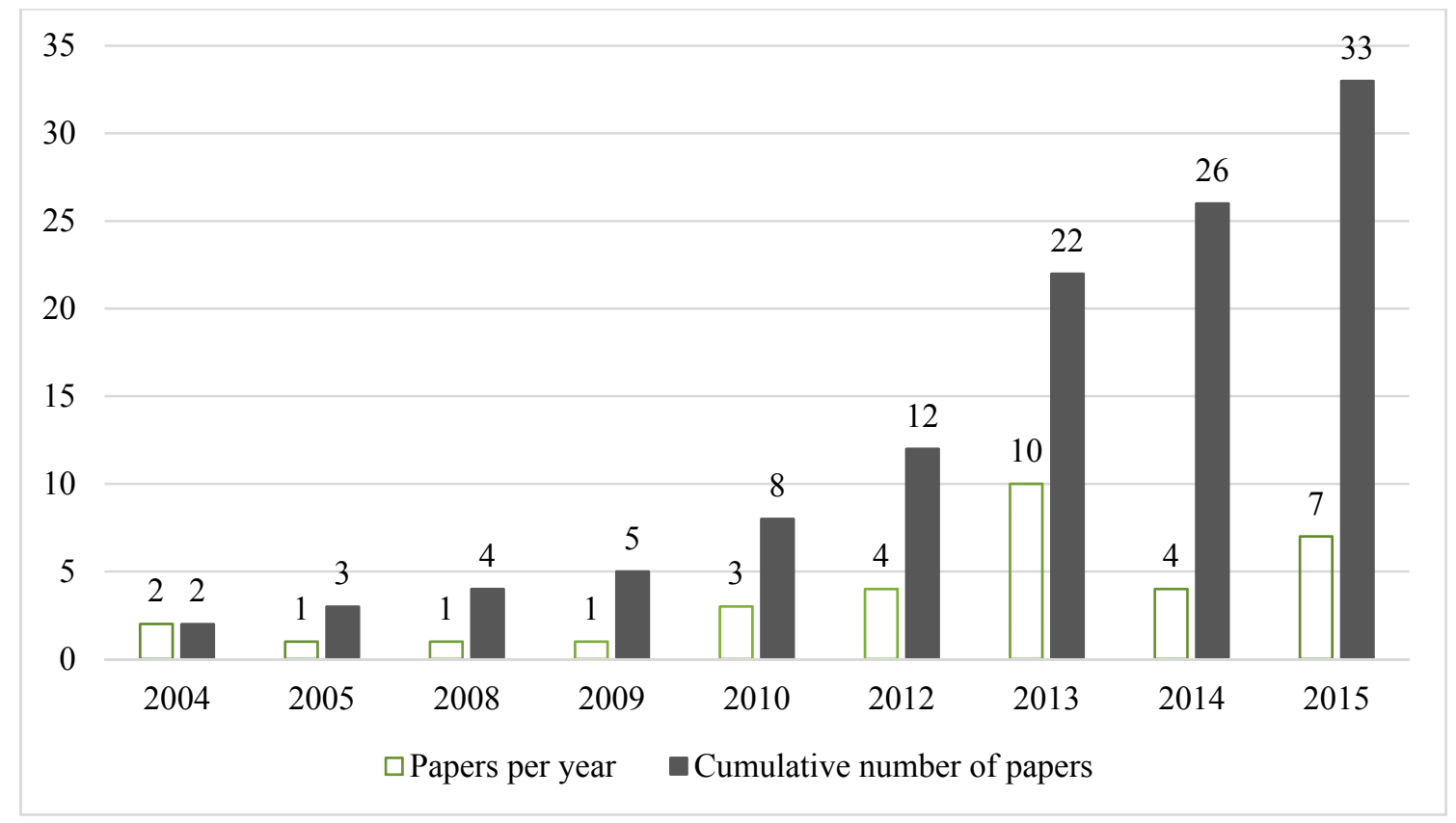

Figure 2. The growth dynamics of the papers included in Thomson Reuters Web of Science Database under the keywords MCDM and renewable energy from 2004-2015. 
Figure 3 presents important evidence based on the frequency of the growth dynamics of the papers included in Thomson Reuters Web of Science database under the keywords MCDM and sustainable energy from 2004-2015. The findings show that from 2004-2015 information about the employment of MCDM techniques in sustainable energy areas increased. According to the results from this figure, the use of these techniques in 2004 was found in two papers, and this number increased to six papers in 2010; the number of publications increased to nine papers in 2013. Accordingly, it can be shown that scholars in the sustainable energy field utilize the MCDM techniques nowadays in their research, and it can be predicted that in coming years these numbers will increase. Outcomes of growth dynamics of the papers are shown in Figure 3.

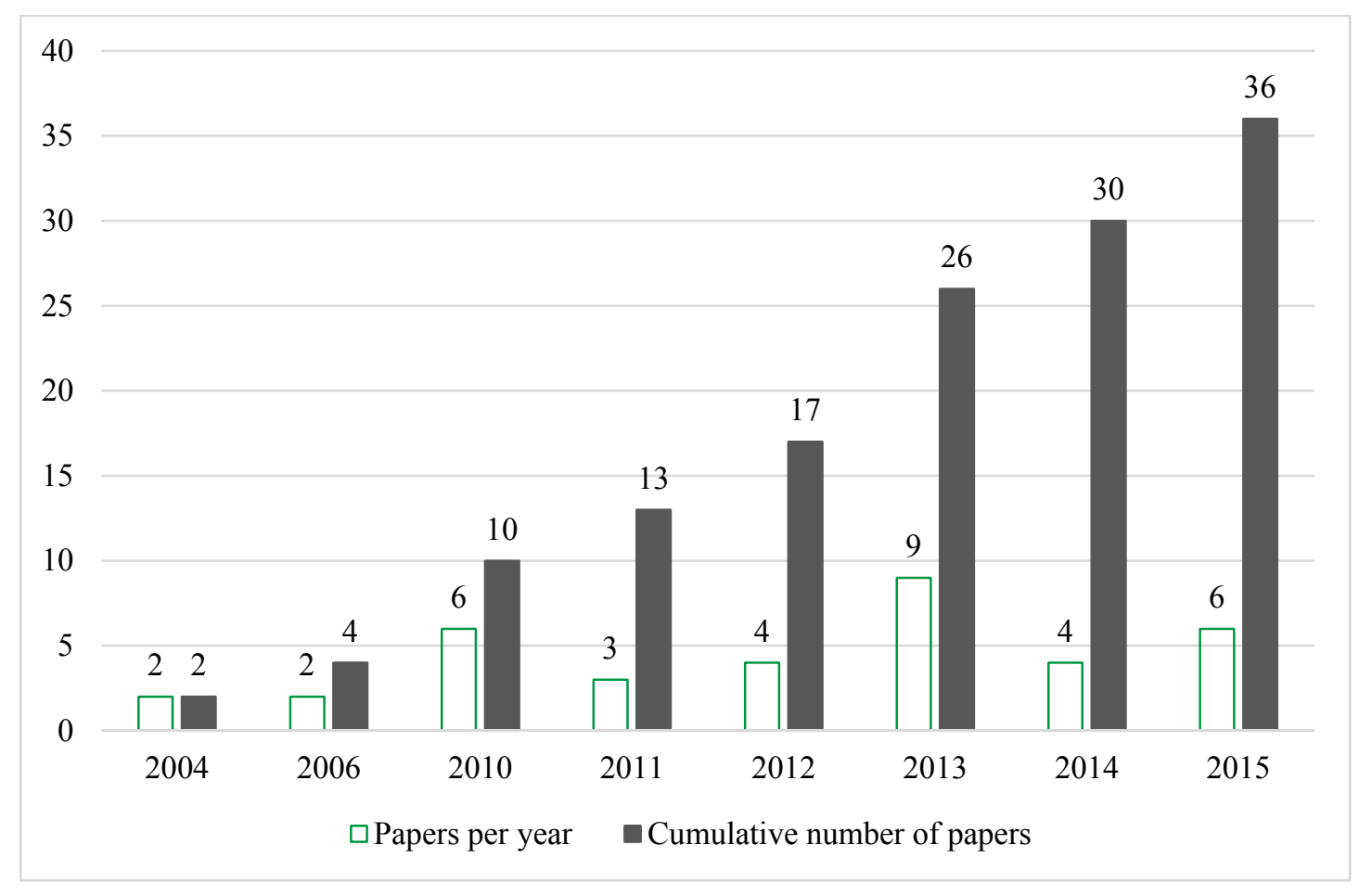

Figure 3. The growth dynamics of the papers included in Thomson Reuters Web of Science Database under the keywords MCDM and sustainable energy from 2004-2015.

After the primary search and collection of these scholarly articles, the articles related to sustainable and renewable energy fields were selected; therefore, in the following section, we have attempted to classify scholarly papers related to these issues based on techniques and approaches. The summary of analysis and procedure of study is shown in Figure 4. 


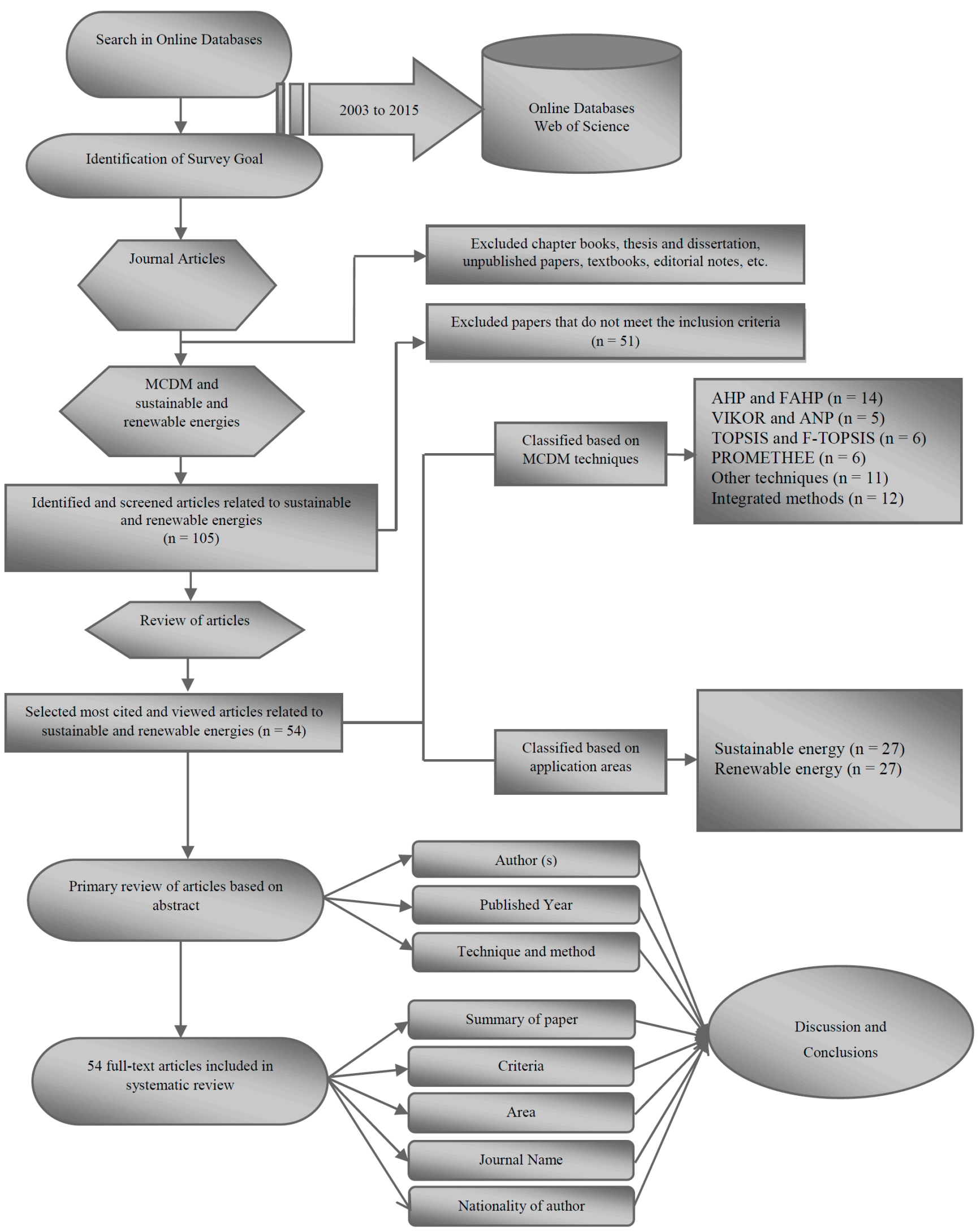

Figure 4. Research methodology procedure. 


\section{Finding}

\subsection{Classifications and Observations}

This survey is based on a literature review and classification of international journal articles in recent years. The majority of the journals are specialist journals in environmental systems, renewable and sustainable energy. Research on MCDM continued and found many applications in different fields. MCDM provides strong decision making in domains where selection of the best alternative is highly complex. This paper reviews the main streams of considerations in multi criteria decision making theory and practice in detail, and it is mainly aimed at identifying various applications and approaches and suggesting approaches that can be most robustly and effectively used to identify the best alternative in the renewable and sustainable energy systems. The MCDM method has been applied in many domains to choose the best alternatives. Where many criteria have come into existence, the best one can be obtained by analyzing the different scopes and weights of the criteria, and the selection of the optimum ones using any multi criteria decision making techniques.

This survey investigates the developments of various methods of MCDM and its applications in renewable and sustainable energy systems. In our daily life, many decisions are being made based on various criteria; thus the decision can be made by assigning weights to different criteria, and all the weights are obtained from expert groups. It is important to determine the structure of the problem and explicitly evaluate multi criteria. For example, in building a nuclear power plant, certain decisions have been taken based on different criteria. There are not only very complex issues involving multi criteria, some criteria may have effect on some problems; however, to have an optimum solution, all alternatives must have common criteria, and this clearly leads to more informed and better decisions. The applications developed to solve multi choice problems and the selected MCDM methods provide better performance in cases such as renewable and sustainable energy systems, safety assessment in marine engineering, watershed location and urban distribution centers in public sectors.

\subsection{Field of Category}

Due to the wide range of applications of MCDM in the real world, there is a strong motivation to categorize these applications across several areas and particular sub-areas such as renewable and sustainable energy systems. The studies that have used MCDM and fuzzy MCDM are categorized into six groups: AHP, VIKOR and ANP, TOPSIS and PROMETHEE, other methods and integrated methods. To identify the differences and similarities, the 54 papers were categorized into two fields: (1) renewable energy and (2) sustainable energy. In the case of the papers that could fall into more than one category, based on the targeted audience defined by the paper's objectives, the best possible choice was selected. This ensured the absence of any duplication in the classification scheme. In the following sections, the papers are briefly presented, and each topic is further summarized using tables corresponding to their sub-areas. In each table, the papers are summarized and highlighted according to their introductions, research criteria, research methods and the results of the study. 


\subsection{Distribution Based on MCDM Techniques and Area of Application}

Table 1 shows the frequency of MCDM and fuzzy MCDM techniques and approaches used in two different topics, sustainable and renewable energy. Based on results presented in this table, a total of 54 studies employed MCDM and fuzzy MCDM techniques and approaches. This table shows that AHP and FAHP methods and their applications have been used more than other tools and approaches. The second rank was integrated techniques and approaches. Other methods, VIKOR, ANP, TOPSIS and F-TOPSIS hold third and fourth ranking with 25 papers (12.69\%). The frequency of techniques and approaches are presented in Table 1.

Table 1. Summary of applications of the DM techniques.

\begin{tabular}{cccc}
\hline DM Techniques & $\begin{array}{c}\text { Frequency Based on } \\
\text { Sustainable Energy }\end{array}$ & $\begin{array}{c}\text { Frequency Based on } \\
\text { Renewable Energy }\end{array}$ & Total \\
\hline AHP and FAHP & 8 & 6 & 14 \\
VIKOR and ANP & 1 & 4 & 5 \\
TOPSIS and F-TOPSIS & 4 & 2 & 6 \\
PROMETHEE & 3 & 3 & 6 \\
Other techniques & 3 & 8 & 11 \\
Integrated methods & 8 & 4 & 12 \\
\hline Total & 27 & 27 & 54 \\
\hline
\end{tabular}

\subsection{Distribution Based on AHP and FAHP}

AHP is one of the most popular techniques in MCDM issues which scholars use for ranking, selection and assessment of criteria. Results of Table 2 show that a total of 14 papers used AHP and FAHP for evaluation of sustainable and renewable energy systems problems; based on these results, five studies have applied both AHP and FAHP for evaluation of renewable energy systems; in addition, eight papers have employed sustainable energy systems. According to findings from this table, one paper was published in 2015; three papers have applied these techniques (s) in 2013, three papers in 2012, one paper in 2011 and two papers in 2010. Results of other years and other information about this category are provided in Table 2.

Table 2. Distributed papers based on AHP and FAHP.

\begin{tabular}{ccccccc}
\hline Author & Year & Nationality & $\begin{array}{c}\text { Technique } \\
\text { and } \\
\text { Application }\end{array}$ & Summary of Paper & Criteria & Area \\
\hline $\begin{array}{c}\text { Heo, } \text { et al. } \\
{[145]}\end{array}$ & 2010 & $\begin{array}{c}\text { Republic of } \\
\text { Korea }\end{array}$ & FAHP & $\begin{array}{c}\text { Applied FAHP for } \\
\text { assessment renewable } \\
\text { energy factors. }\end{array}$ & $\begin{array}{c}\text { Technological, market, economic, } \\
\text { environmental and policy. }\end{array}$ & renewable \\
energy \\
$\begin{array}{c}\text { Davoudpour, } \\
\text { et al. }[146]\end{array}$
\end{tabular}


Table 2. Cont.

\begin{tabular}{|c|c|c|c|c|c|c|}
\hline Author & Year & Nationality & $\begin{array}{l}\text { Technique } \\
\text { and } \\
\text { Application }\end{array}$ & Summary of Paper & Criteria & Area \\
\hline $\begin{array}{c}\text { Ertay, et al. } \\
\text { [147] }\end{array}$ & 2013 & Turkey & fuzzy AHP & $\begin{array}{l}\text { Assessed renewable } \\
\text { energy development by } \\
\text { utilized fuzzy AHP. }\end{array}$ & $\begin{array}{l}\text { Risk \& feasibility, continuity and } \\
\text { predictability, reliability, duration of } \\
\text { prep \& implement, local technic } \\
\text { knowhow, pollutant emission land } \\
\text { requirements, need of waste disposal, } \\
\text { compatibility with the national energy } \\
\text { policy objective, political acceptance, } \\
\text { social acceptance, labor impact, } \\
\text { implementation cost, availability of } \\
\text { funds and economic value. }\end{array}$ & $\begin{array}{c}\text { renewable } \\
\text { energy }\end{array}$ \\
\hline $\begin{array}{c}\text { Karaca, et al. } \\
{[148]}\end{array}$ & 2015 & Turkey & AHP & $\begin{array}{l}\text { Used AHP for selection } \\
\text { of energy and water } \\
\text { sustainability } \\
\text { infrastructure. }\end{array}$ & $\begin{array}{l}\text { Social, environmental and techno- } \\
\text { economic criteria and sub-criteria. }\end{array}$ & $\begin{array}{c}\text { sustainable } \\
\text { energy }\end{array}$ \\
\hline $\begin{array}{l}\text { Shen, Lin, Li } \\
\text { and Yuan } \\
\text { [79] }\end{array}$ & 2010 & Taiwan & Fuzzy AHP & $\begin{array}{l}\text { Employed FAHP for } \\
\text { evaluation of } \\
\text { renewable } \\
\text { energy sources. }\end{array}$ & $\begin{array}{l}\text { Energy price stability, security for } \\
\text { energy supply, low energy prices, } \\
\text { stability for energy generation, carbon } \\
\text { emissions reduction, SOx and NOx } \\
\text { emissions reductions, environmental } \\
\text { sustainability, low land requirement, } \\
\text { local economic development, local } \\
\text { economic development, technical } \\
\text { maturity, potential for } \\
\text { commercialization, market size and } \\
\text { reasonableness for investment cost. }\end{array}$ & $\begin{array}{c}\text { renewable } \\
\text { energy }\end{array}$ \\
\hline $\begin{array}{c}\text { Pons and } \\
\text { Aguado } \\
{[149]}\end{array}$ & 2012 & Spain & AHP & $\begin{array}{l}\text { Applied AHP for } \\
\text { sustainability } \\
\text { assessment in } \\
\text { schools building. }\end{array}$ & $\begin{array}{l}\text { Cost, time, extraction and fabrication } \\
\text { of materials, transport, building and } \\
\text { assembly, use and maintenance, } \\
\text { demolition, adaptability to changes } \\
\text { and users' safety. }\end{array}$ & $\begin{array}{c}\text { sustainable } \\
\text { energy }\end{array}$ \\
\hline $\begin{array}{l}\text { Kahraman, } \\
\text { et al. }[150]\end{array}$ & 2009 & Turkey & fuzzy AHP & $\begin{array}{c}\text { Employed fuzzy AHP } \\
\text { for evaluation of } \\
\text { renewable energy } \\
\text { alternatives. }\end{array}$ & $\begin{array}{l}\text { Technological criteria, energy and } \\
\text { environmental, criteria, social and } \\
\text { economic criteria. }\end{array}$ & $\begin{array}{c}\text { renewable } \\
\text { energy }\end{array}$ \\
\hline $\begin{array}{c}\text { Reza, et al. } \\
{[151]}\end{array}$ & 2011 & Canada & AHP & $\begin{array}{l}\text { Employed AHP for } \\
\text { sustainability } \\
\text { assessment. }\end{array}$ & $\begin{array}{l}\text { Resource depletion, energy loss, } \\
\text { waste and waste management, climate } \\
\text { change, environmental risk, embodied } \\
\text { energy, material cost, performance } \\
\text { cost, operation \& maintenance cost, } \\
\text { social acceptance vulnerability of area } \\
\text { and building. }\end{array}$ & $\begin{array}{c}\text { sustainable } \\
\text { energy }\end{array}$ \\
\hline
\end{tabular}


Table 2. Cont.

\begin{tabular}{|c|c|c|c|c|c|c|}
\hline Author & Year & Nationality & $\begin{array}{l}\text { Technique } \\
\text { and } \\
\text { Application }\end{array}$ & Summary of Paper & Criteria & Area \\
\hline $\begin{array}{l}\text { Pons and de } \\
\text { la Fuente } \\
\text { [152] }\end{array}$ & 2013 & Spain & AHP & $\begin{array}{l}\text { Used AHP for } \\
\text { integrated } \\
\text { sustainability } \\
\text { assessment. }\end{array}$ & $\begin{array}{l}\text { Construction costs, efficiency, } \\
\text { emissions, resources consumption, } \\
\text { negative effects on the producer } \\
\text { industry and effects to third party. }\end{array}$ & $\begin{array}{c}\text { sustainable } \\
\text { energy }\end{array}$ \\
\hline $\begin{array}{c}\text { Aras, et al. } \\
\text { [153] }\end{array}$ & 2004 & Turkey & AHP & $\begin{array}{c}\text { Applied AHP for } \\
\text { location selection of } \\
\text { wind observation station. }\end{array}$ & $\begin{array}{l}\text { Convenience of transportation, cost, } \\
\text { security, topography and } \\
\text { infrastructure with } 12 \text { sub-criteria. }\end{array}$ & $\begin{array}{c}\text { sustainable } \\
\text { energy }\end{array}$ \\
\hline $\begin{array}{l}\text { Nigim, et al. } \\
\text { [154] }\end{array}$ & 2004 & Canada & AHP & $\begin{array}{l}\text { Employed AHP for } \\
\text { ranking of renewable } \\
\text { energy sources. }\end{array}$ & $\begin{array}{l}\text { Resource availability, financial } \\
\text { viability, social benefits, educational } \\
\text { potential, ecological impact, project } \\
\text { feasibility, technical feasibility and } \\
\text { economic benefits. }\end{array}$ & $\begin{array}{c}\text { renewable } \\
\text { energy }\end{array}$ \\
\hline $\begin{array}{c}\text { Lee, et al. } \\
\text { [155] }\end{array}$ & 2009 & Taiwan, & AHP & $\begin{array}{l}\text { Used AHP for wind } \\
\text { farms selection. }\end{array}$ & $\begin{array}{l}\text { Wind availability, site advantage, } \\
\text { WEG functions, financial schemes, } \\
\text { policy support, advanced } \\
\text { technologies, wind turbine, } \\
\text { connection, foundation, concept } \\
\text { conflict, technical risks and } \\
\text { uncertainty of land. }\end{array}$ & $\begin{array}{c}\text { renewable } \\
\text { energy }\end{array}$ \\
\hline $\begin{array}{l}\text { Al-Yahyai, } \\
\text { et al. [156] }\end{array}$ & 2012 & Oman & AHP-OWA & $\begin{array}{l}\text { Used AHP-OWA } \\
\text { for wind farm } \\
\text { siting evaluation. }\end{array}$ & $\begin{array}{l}\text { Wind power density, peak hours } \\
\text { matching, wind occurrence, } \\
\text { turbulence intensity and } \\
\text { wind occurrence. }\end{array}$ & $\begin{array}{c}\text { renewable } \\
\text { energy }\end{array}$ \\
\hline $\begin{array}{l}\text { Peterseim, } \\
\text { et al. [157] }\end{array}$ & 2013 & Australia & AHP & $\begin{array}{l}\text { Applied AHP for } \\
\text { identify of the suitable } \\
\text { concentrated } \\
\text { solar power. }\end{array}$ & $\begin{array}{l}\text { Peak solar to electricity efficiency, } \\
\text { suitable operation range, maximum } \\
\text { site gradient, technology maturity, } \\
\text { plant complexity, integration } \\
\text { simplicity, land use, cleaning water } \\
\text { consumption, criteria groups } \\
\text { feasibility, risk reduction, impact } \\
\text { reduction and LCOE. }\end{array}$ & $\begin{array}{c}\text { renewable } \\
\text { energy }\end{array}$ \\
\hline
\end{tabular}

\subsection{Distribution Based on VIKOR and ANP}

The second group of MCDM techniques is VIKOR and ANP which were used for assessment of sustainable and renewable energy systems problems. According to results of Table 3 we can show that, in total, only five papers have used both ANP and VIKOR techniques. Findings of this table show that two papers used the VIKOR technique and three papers applied the ANP method. Moreover, this table shows four previous scholars used these techniques for evaluation of renewable energy systems problems and one study was applied to evaluation of sustainable energy systems problems. Furthermore, based on information in this table, two papers were published in 2014 and one paper in 2013, 2012 and 2011. Other information on this group is presented in Table 3. 
Table 3. Distributed papers based on VIKOR and ANP.

\begin{tabular}{|c|c|c|c|c|c|c|}
\hline Author & Year & Nationality & $\begin{array}{l}\text { Technique } \\
\text { and } \\
\text { Application }\end{array}$ & Summary of Paper & Criteria & Area \\
\hline $\begin{array}{c}\text { San Cristóbal } \\
{[158]}\end{array}$ & 2011 & Romania & VIKOR & $\begin{array}{l}\text { Assessed renewable } \\
\text { energy projects by } \\
\text { used VIKOR. }\end{array}$ & $\begin{array}{l}\text { Power, investment ratio, } \\
\text { implementation period, } \\
\text { operating hours, useful life, } \\
\text { operation and maintenance costs } \\
\text { and Tons of } \mathrm{CO}_{2} \text { avoided. }\end{array}$ & $\begin{array}{c}\text { renewable } \\
\text { energy }\end{array}$ \\
\hline $\begin{array}{l}\text { Vučijak, } \\
\text { et al. [159] }\end{array}$ & 2013 & $\begin{array}{l}\text { Bosnia and } \\
\text { Herzegovina }\end{array}$ & VIKOR & $\begin{array}{l}\text { Assessed sustainable } \\
\text { hydropower by } \\
\text { applied VIKOR. }\end{array}$ & 23 environmental criteria & $\begin{array}{l}\text { sustainabl } \\
\text { e energy }\end{array}$ \\
\hline $\begin{array}{l}\text { Cannemi, } \\
\text { et al. }[160]\end{array}$ & 2014 & Italy & ANP & $\begin{array}{c}\text { Employed ANP for } \\
\text { development of } \\
\text { renewable energy } \\
\text { based on selection } \\
\text { of biomass } \\
\text { power plants. }\end{array}$ & $\begin{array}{l}\text { Food demand, global effects, } \\
\text { local effects, policies \& } \\
\text { strategies, social development, } \\
\text { centralization/decentralization, } \\
\text { conventional/renewable energy } \\
\text { integration, heating } \\
\text { (cooling)/electricity integration, } \\
\text { industrial, infrastructure and } \\
\text { technological development, } \\
\text { financials, incomes, logistics } \\
\text { and O\&M. }\end{array}$ & $\begin{array}{c}\text { renewable } \\
\text { energy }\end{array}$ \\
\hline $\begin{array}{l}\text { Shiue and } \\
\text { Lin [161] }\end{array}$ & 2012 & Taiwan & ANP & $\begin{array}{l}\text { Used ANP for } \\
\text { assessment of } \\
\text { optimal recycling } \\
\text { strategy. }\end{array}$ & $\begin{array}{l}\text { BSC factors include; benefits, } \\
\text { opportunities, costs, risks and } \\
\text { collection strategy. }\end{array}$ & $\begin{array}{c}\text { renewable } \\
\text { energy }\end{array}$ \\
\hline $\begin{array}{c}\text { Kabak and } \\
\text { Dağdeviren } \\
{[162]}\end{array}$ & 2014 & Turkey & ANP & $\begin{array}{l}\text { Used ANP for } \\
\text { ranking of renewable } \\
\text { energy resources. }\end{array}$ & $\begin{array}{l}\text { Technology, economy, } \\
\text { security and global effects and } \\
\text { human wellbeing. }\end{array}$ & $\begin{array}{c}\text { renewable } \\
\text { energy }\end{array}$ \\
\hline
\end{tabular}

\subsection{Distribution Based on TOPSIS and F-TOPSIS}

Results of Table 4 indicate that some of the previous scholars used TOPSIS and F-TOPSIS for evaluation of their problems in fields of renewable and sustainable energy systems. According to this table, six papers have applied both TOPSIS and F-TOPSIS. In addition, based on these findings, two studies implemented TOPSIS and F-TOPSIS for assessment of renewable energy systems problems and four studies utilized both TOPSIS and F-TOPSIS for solving problems in sustainable energy systems. Moreover, based on of this table, we show that three papers used classical TOPSIS and three papers applied fuzzy TOPSIS. Furthermore, the results of this table show one paper in 2015, one paper in 2014, one paper in 2013 and one paper in 2011 used TOPSIS and F-TOPSIS. Other information about this category is presented in Table 4. 
Table 4. Distributed papers based on TOPSIS.

\begin{tabular}{|c|c|c|c|c|c|c|}
\hline Author & Year & Nationality & $\begin{array}{l}\text { Technique } \\
\text { and } \\
\text { Application }\end{array}$ & Summary of Paper & Criteria & Area \\
\hline $\begin{array}{c}\text { Doukas and } \\
\text { Psarras } \\
\text { [163] }\end{array}$ & 2009 & Greece & TOPSIS & $\begin{array}{l}\text { Assessed renewable } \\
\text { energy development } \\
\text { by applied TOPSIS. }\end{array}$ & $\begin{array}{l}\text { GHG emissions reduction, impact on } \\
\text { the natural environment, contribution } \\
\text { to employment, local and regional } \\
\text { economic development, investment } \\
\text { cost and contribution to energy } \\
\text { sufficiency. }\end{array}$ & $\begin{array}{c}\text { renewable } \\
\text { energy }\end{array}$ \\
\hline $\begin{array}{c}\text { Cavallaro } \\
\text { [164] }\end{array}$ & 2010 & Italy & $\begin{array}{l}\text { Fuzzy } \\
\text { TOPSIS }\end{array}$ & $\begin{array}{l}\text { Applied F-TOPSIS } \\
\text { for evaluation of } \\
\text { thermal-energy } \\
\text { storage. }\end{array}$ & $\begin{array}{l}\text { Investment costs, land use, operating } \\
\text { and maintenance costs, levelized } \\
\text { electricity cost, levelized electricity } \\
\text { cost, thermal storage costs, electricity } \\
\text { production, state of knowledge of } \\
\text { innovative technology, environmental } \\
\text { risk and safety and freezing point. }\end{array}$ & $\begin{array}{c}\text { sustainable } \\
\text { energy }\end{array}$ \\
\hline $\begin{array}{l}\text { Perera, } \\
\text { et al. }[165]\end{array}$ & 2013 & Sri Lanka & $\begin{array}{l}\text { Fuzzy } \\
\text { TOPSIS }\end{array}$ & $\begin{array}{l}\text { Employed } \\
\text { F-TOPSIS for } \\
\text { assessment of } \\
\text { standalone hybrid } \\
\text { energy systems. }\end{array}$ & $\begin{array}{l}\text { LEC, unmet fraction, fuel, WRE, SPV } \\
\text { panels, wind turbines, ICG capacity } \\
\text { and battery banks. }\end{array}$ & $\begin{array}{c}\text { sustainable } \\
\text { energy }\end{array}$ \\
\hline $\begin{array}{l}\text { Kucukvar, } \\
\text { et al. }[166]\end{array}$ & 2014 & USA & TOPSIS & $\begin{array}{c}\text { Applied TOPSIS } \\
\text { for ranking of cycle } \\
\text { sustainability } \\
\text { performance. }\end{array}$ & $\begin{array}{l}\text { Environmental and socio economic } \\
\text { criteria and sub-criteria. }\end{array}$ & $\begin{array}{c}\text { sustainable } \\
\text { energy }\end{array}$ \\
\hline $\begin{array}{l}\text { Lozano- } \\
\text { Minguez, } \\
\text { et al. [167] }\end{array}$ & 2011 & $\begin{array}{l}\text { United } \\
\text { Kingdom }\end{array}$ & TOPSIS & $\begin{array}{l}\text { Applied TOPSIS } \\
\text { for evaluation of } \\
\text { offshore wind } \\
\text { turbine. }\end{array}$ & $\begin{array}{l}\text { Artificial reefs, certification, } \mathrm{CO} 2 \mathrm{e} \\
\text { emission, depth compatibility, } \\
\text { maximum displacement, durability, } \\
\mathrm{NPV} \text {, maximum von Mises stress and } \\
\text { water turbidity. }\end{array}$ & $\begin{array}{c}\text { sustainable } \\
\text { energy }\end{array}$ \\
\hline $\begin{array}{l}\text { Şengül, } \\
\text { et al. }[168]\end{array}$ & 2015 & Turkey & $\begin{array}{l}\text { Fuzzy } \\
\text { TOPSIS }\end{array}$ & $\begin{array}{l}\text { Used F-TOPSIS for } \\
\text { ranking of } \\
\text { renewable energy } \\
\text { supply systems. }\end{array}$ & $\begin{array}{l}\text { Technical (efficiency, installed } \\
\text { capacity, amount of energy produced), } \\
\text { economic (investment cost, operation } \\
\text { and maintenance cost, payback } \\
\text { period), environmental (land use, } \\
\text { value of } \mathrm{CO}_{2} \text { emission) and social } \\
\text { (job creation). }\end{array}$ & $\begin{array}{c}\text { renewable } \\
\text { energy }\end{array}$ \\
\hline
\end{tabular}

\subsection{Distribution Based on PROMETHEE}

The PROMETHEE technique is the third group which was used for this study. Based on results of Table 5, we show that six previous studies utilized PROMETHEE. Findings of this table revealed that three papers used PROMETHEE for assessment of renewable energy issues and three papers implemented it for evaluation of sustainable energy systems. Moreover, this table shows the previous 
studies published: one paper in 2014, three papers in 2009 and one paper in both 2004 and 2003. Other findings of this classification are provided in Table 5.

Table 5. Distributed papers based on PROMETHEE.

\begin{tabular}{|c|c|c|c|c|c|c|}
\hline Author & Year & Nationality & $\begin{array}{c}\text { Technique and } \\
\text { Application }\end{array}$ & Summary of Paper & Criteria & Area \\
\hline $\begin{array}{l}\text { Haralambopoulos } \\
\text { and Polatidis [169] }\end{array}$ & 2003 & Greece & $\begin{array}{c}\text { PROMETHEE } \\
\text { II }\end{array}$ & $\begin{array}{c}\text { Assessed renewable } \\
\text { energy projects by applied } \\
\text { PROMETHEE II. } \\
\end{array}$ & $\begin{array}{l}\text { Fuel saved, return on investment, no of } \\
\text { jobs created, environmental index and } \\
\text { risk index. }\end{array}$ & $\begin{array}{c}\text { renewable } \\
\text { energy }\end{array}$ \\
\hline $\begin{array}{l}\text { Troldborg, Heslop } \\
\text { and Hough [88] }\end{array}$ & 2014 & $\begin{array}{c}\text { United } \\
\text { Kingdom }\end{array}$ & PROMETHEE & $\begin{array}{l}\text { Assessed of energy } \\
\text { renewable sustainability } \\
\text { technologies by used } \\
\text { PROMETHEE. }\end{array}$ & $\begin{array}{l}\text { Total power generation, technology } \\
\text { maturity, reliability of supply, GHG } \\
\text { emissions impact on amenity, area } \\
\text { requirements, levelized energy, cost, } \\
\text { contribution to economy and social } \\
\text { acceptance. }\end{array}$ & $\begin{array}{c}\text { sustainable } \\
\text { energy }\end{array}$ \\
\hline $\begin{array}{l}\text { Tsoutsos, Drandaki, } \\
\text { Frantzeskaki, } \\
\text { Iosifidis and Kiosses } \\
\text { [95] }\end{array}$ & 2009 & Greece & $\begin{array}{l}\text { PROMETHEE I } \\
\text { and } \\
\text { PROMETHEE } \\
\text { II }\end{array}$ & $\begin{array}{l}\text { Employed PROMETHEE } \\
\text { I and PROMETHEE II for } \\
\text { assessment of sustainable } \\
\text { energy planning }\end{array}$ & $\begin{array}{l}\text { Investment, operating and maintenance } \\
\text { cost, conventional fuels savings, } \\
\text { maturity of technology, safety of } \\
\text { supply, emissions avoided and } \\
\text { contribution to local development and } \\
\text { welfare. }\end{array}$ & $\begin{array}{c}\text { sustainable } \\
\text { energy }\end{array}$ \\
\hline $\begin{array}{c}\text { Mohamadabadi, } \\
\text { et al. }[170]\end{array}$ & 2009 & Canada & PROMETHEE & $\begin{array}{l}\text { Used PROMETHEE for } \\
\text { selection of best } \\
\text { fuel-based vehicles } \\
\text { based on renewable and } \\
\text { non-renewable } \\
\text { assessment. }\end{array}$ & $\begin{array}{l}\text { Fuel cost, vehicle cost, refueling station } \\
\text { distance, GHG emission and number of } \\
\text { customer options. }\end{array}$ & $\begin{array}{c}\text { renewable } \\
\text { energy }\end{array}$ \\
\hline $\begin{array}{c}\text { Pohekar and } \\
\text { Ramachandran } \\
\text { [171] }\end{array}$ & 2004 & India & PROMETHEE & $\begin{array}{l}\text { Used PROMETHEE for } \\
\text { assessment of cooking } \\
\text { energy substitution. }\end{array}$ & $\begin{array}{l}\text { Chulha, improved chulha, Kerosene } \\
\text { stove, biogas stove, LPG stove, micro- } \\
\text { wave oven, electric oven, solar box } \\
\text { cooker and PSC. }\end{array}$ & $\begin{array}{c}\text { renewable } \\
\text { energy }\end{array}$ \\
\hline Cavallaro [172] & 2009 & Italy & PROMETHEE & $\begin{array}{l}\text { Applied PROMETHEE } \\
\text { for evaluation of solar } \\
\text { thermal technologies. }\end{array}$ & $\begin{array}{l}\text { Investment cost, O\&M cost, LEC, } \\
\text { maturity of technology, environmental } \\
\text { impact, temperature and solar capacity } \\
\text { factor. }\end{array}$ & $\begin{array}{c}\text { sustainable } \\
\text { energy }\end{array}$ \\
\hline
\end{tabular}

\subsection{Distribution Based on Other Techniques}

Results of Table 6 show, in total, 11 papers have implemented other MCDM techniques and approaches. Findings of this table revealed that eight papers for solving problems in the field of sustainable energy used these techniques. Some of the techniques in this group are multi criteria analysis (MCA), MULTIMOORA, ELECTRE, COPRAS, etc. Moreover, this table shows five papers published in 2015, two papers in 2014 and two papers in 2013. Results of other years are provided in Table 6. 
Table 6. Distributed papers based on other techniques.

\begin{tabular}{|c|c|c|c|c|c|c|}
\hline Author & Year & Nationality & $\begin{array}{l}\text { Technique } \\
\text { and } \\
\text { Application }\end{array}$ & Summary of Paper & Criteria & Area \\
\hline Chang [173] & 2015 & Taiwan & $\begin{array}{l}\text { Multi-choice } \\
\text { goal } \\
\text { programming }\end{array}$ & $\begin{array}{c}\text { Employed } \\
\text { Multi-choice goal } \\
\text { programming for } \\
\text { selection the best } \\
\text { location for facilities } \\
\text { of renewable energy }\end{array}$ & $\begin{array}{l}\text { Power generated, investment cost, } \\
\text { emissions, jobs created, operation } \\
\text { and maintenance costs, distance } \\
\text { between plants and social } \\
\text { acceptance }\end{array}$ & $\begin{array}{c}\text { renewable } \\
\text { energy }\end{array}$ \\
\hline $\begin{array}{l}\text { Buchholz, } \\
\text { et al. }[174]\end{array}$ & 2009 & USA & $\mathrm{MCA}$ & $\begin{array}{l}\text { Applied MCA for } \\
\text { evaluation of } \\
\text { sustainable } \\
\text { bioenergy projects. }\end{array}$ & $\begin{array}{l}\text { Stakeholder inclusion in } \\
\text { decision-making, application of } \\
\text { qualitative data, measures to deal } \\
\text { with uncertainty, inclusion of } \\
\text { criteria hierarchies, use of } \\
\text { thresholds, ease of computation, } \\
\text { dynamic reevaluation, transparency } \\
\text { and communication of decision } \\
\text { process and results. }\end{array}$ & $\begin{array}{c}\text { sustainable } \\
\text { energy }\end{array}$ \\
\hline $\begin{array}{c}\text { Santoyo- } \\
\text { Castelazo and } \\
\text { Azapagic } \\
{[175]}\end{array}$ & 2014 & UK & MAVT & $\begin{array}{c}\text { Assessed of } \\
\text { sustainability in } \\
\text { energy systems by } \\
\text { used MAVT. }\end{array}$ & $\begin{array}{l}\text { Costs. climate change and human } \\
\text { toxicity with sub-criteria }\end{array}$ & $\begin{array}{c}\text { sustainable } \\
\text { energy }\end{array}$ \\
\hline $\begin{array}{l}\text { Balezentiene, } \\
\text { Streimikiene } \\
\text { and Balezentis } \\
\qquad[84]\end{array}$ & 2013 & Lithuania & $\begin{array}{c}\text { Fuzzy } \\
\text { MULTIMOO } \\
\text { RA }\end{array}$ & $\begin{array}{c}\text { Assessed sustainable } \\
\text { energy by applied } \\
\text { Fuzzy } \\
\text { MULTIMOORA. }\end{array}$ & $\begin{array}{l}\text { Soil carbon sequestration, } \\
\text { photosynthesis type, water } \\
\text { adaptation, DM, thaha }{ }^{-1} \text {, erosion } \\
\text { control, input requirement and } \\
\text { energy yield, GJ } \cdot \mathrm{ha}^{-1} \text {. }\end{array}$ & $\begin{array}{c}\text { sustainable } \\
\text { energy }\end{array}$ \\
\hline $\begin{array}{l}\text { Mainali and } \\
\text { Silveira [176] }\end{array}$ & 2015 & Sweden & $\mathrm{MCA}$ & $\begin{array}{l}\text { Used MCA for } \\
\text { assessment of energy } \\
\text { sustainability } \\
\text { technologies. }\end{array}$ & $\begin{array}{l}\text { Energy availability, efficiency of } \\
\text { energy generation, reliability, } \\
\text { capital investment, O\&M cost, fuel } \\
\text { cost, GHG emission, land uses, } \\
\text { local employment generation, } \\
\text { compatibility of the technology to } \\
\text { do end uses and operational } \\
\text { \&management capability required. }\end{array}$ & $\begin{array}{c}\text { sustainable } \\
\text { energy }\end{array}$ \\
\hline $\begin{array}{l}\text { Patlitzianas, } \\
\text { et al. }[177]\end{array}$ & 2007 & Greece & OWA & $\begin{array}{l}\text { Used OWA for } \\
\text { evaluation of } \\
\text { renewable energy } \\
\text { producers. }\end{array}$ & $\begin{array}{l}\text { Political/legal, financial, } \\
\text { social/cultural and technological } \\
\text { with } 24 \text { sub-criteria. }\end{array}$ & $\begin{array}{c}\text { renewable } \\
\text { energy }\end{array}$ \\
\hline
\end{tabular}


Table 6. Cont.

\begin{tabular}{|c|c|c|c|c|c|c|}
\hline Author & Year & Nationality & $\begin{array}{c}\text { Technique } \\
\text { and } \\
\text { Application }\end{array}$ & Summary of Paper & Criteria & Area \\
\hline $\begin{array}{c}\text { Aydin, et al. } \\
{[178]}\end{array}$ & 2013 & Germany & OWA & $\begin{array}{l}\text { Applied OWA for } \\
\text { selection of } \\
\text { GIS-based site for } \\
\text { renewable energy. }\end{array}$ & $\begin{array}{l}\text { Environmental, economic and } \\
\text { criteria and sub-criteria. }\end{array}$ & $\begin{array}{c}\text { renewable } \\
\text { energy }\end{array}$ \\
\hline $\begin{array}{l}\text { Egilmez, et al. } \\
\text { [179] }\end{array}$ & 2015 & $\begin{array}{l}\text { United } \\
\text { States }\end{array}$ & FMCDM & $\begin{array}{l}\text { Implemented } \\
\text { FMCDM for } \\
\text { benchmarking of } \\
\text { environmental } \\
\text { sustainability. }\end{array}$ & 16 criteria & $\begin{array}{c}\text { sustainable } \\
\text { energy }\end{array}$ \\
\hline $\begin{array}{l}\text { Nuuter, et al. } \\
\text { [180] }\end{array}$ & 2015 & Estonia & COPRAS & $\begin{array}{l}\text { Employed COPRAS } \\
\text { for evaluation of } \\
\text { sustainability of } \\
\text { housing market. }\end{array}$ & $\begin{array}{l}\text { General economic, housing stock, } \\
\text { population and social condition, } \\
\text { housing quality, housing affordability } \\
\text { and environmental quality. }\end{array}$ & $\begin{array}{c}\text { sustainable } \\
\text { energy }\end{array}$ \\
\hline $\begin{array}{c}\text { Sánchez- } \\
\text { Lozano, et al. } \\
\text { [181] }\end{array}$ & 2014 & Spain & $\begin{array}{l}\text { ELECTRE- } \\
\text { TRI }\end{array}$ & $\begin{array}{c}\text { Applied } \\
\text { ELECTRE-TRI for } \\
\text { selection of } \\
\text { photovoltaic solar } \\
\text { farms site. }\end{array}$ & $\begin{array}{l}\text { Plot, zone and subplot, agrological } \\
\text { capacity, slope, field orientation, } \\
\text { plot area, distance to main roads, } \\
\text { distance to power lines, distance to } \\
\text { town or villages, distance to } \\
\text { electricity transformer substations, } \\
\text { solar radiation and average } \\
\text { temperature. }\end{array}$ & $\begin{array}{c}\text { sustainable } \\
\text { energy }\end{array}$ \\
\hline $\begin{array}{c}\text { Latinopoulos } \\
\text { and Kechagia } \\
\text { [182] }\end{array}$ & 2015 & Greece & $\begin{array}{l}\text { Weighted } \\
\text { linear } \\
\text { combination } \\
\text { (WLC) }\end{array}$ & $\begin{array}{l}\text { Used WLC for } \\
\text { selection of wind } \\
\text { farm site. }\end{array}$ & $\begin{array}{l}\text { Protected landscapes, archeological } \\
\text { sites, historical sites, urban areas \& } \\
\text { traditional settlements, tourism } \\
\text { facilities, distance from roads, land } \\
\text { use restrictions, wind speed, } \\
\text { proximity to airports and slope. }\end{array}$ & $\begin{array}{c}\text { sustainable } \\
\text { energy }\end{array}$ \\
\hline
\end{tabular}

\subsection{Distribution Based on Integrated Methods}

The last group of our classification in Table 7 is those studies which used MCDM integrated methods. In this group, 12 papers have used MCDM integrated methods: four papers assessed problems in renewable energy systems and eight papers evaluated sustainable energy systems. According to the findings of this group, some integrated methods are AHP mixed with PROMETHEE, TOPSIS mixed with MULTIMOORA, AHP mixed with ROMETHEE II and SWARA mixed with WASPAS, etc. In addition, this table shows four studies utilized these DM integrated methods in 2015, three papers in 2014, two papers in 2013 and one paper in 2012, etc. Other information on this group is represented in Table 7. 
Table 7. Distributed papers based on integrated methods.

\begin{tabular}{|c|c|c|c|c|c|c|}
\hline Author & Year & Nationality & $\begin{array}{l}\text { Technique } \\
\text { and } \\
\text { Application }\end{array}$ & Summary of Paper & Criteria & Area \\
\hline $\begin{array}{c}\text { Yazdani- } \\
\text { Chamzini, et al. } \\
\text { [183] }\end{array}$ & 2013 & Iran & $\begin{array}{l}\text { COPRAS and } \\
\text { AHP }\end{array}$ & $\begin{array}{c}\text { Employed } \\
\text { COPRAS-AHP for } \\
\text { selection renewable } \\
\text { energy }\end{array}$ & $\begin{array}{l}\text { Power, investment ratio, } \\
\text { implementation period, } \\
\text { operating hours, useful life, } \\
\text { operation and maintenance costs, } \\
\text { and tons of emissions of } \mathrm{CO}_{2} \\
\text { avoided per } \\
\text { year. }\end{array}$ & $\begin{array}{c}\text { renewable } \\
\text { energy }\end{array}$ \\
\hline $\begin{array}{l}\text { Kuleli Pak, } \\
\text { et al. }[184]\end{array}$ & 2015 & Turkey & $\begin{array}{l}\text { TOPSIS and } \\
\text { ANP }\end{array}$ & $\begin{array}{l}\text { Evaluated renewable } \\
\text { energy development by } \\
\text { used TOPSIS and ANP. }\end{array}$ & $\begin{array}{l}\text { Accident fatalities, energy use } \\
\text { per capita, supply efficiency of } \\
\text { energy, import dependency, } \\
\text { climate change, water quality } \\
\text { and soil area where acidification } \\
\text { exceeds critical load. }\end{array}$ & $\begin{array}{c}\text { renewable } \\
\text { energy }\end{array}$ \\
\hline $\begin{array}{l}\text { Streimikiene, } \\
\text { Balezentis, } \\
\text { Krisciukaitienè } \\
\text { and Balezentis } \\
\quad[77] \\
\end{array}$ & 2012 & Lithuania & $\begin{array}{l}\text { TOPSIS and } \\
\text { MULTIMOO } \\
\text { RA }\end{array}$ & $\begin{array}{l}\text { Used TOPSIS and } \\
\text { MULTIMOORA for } \\
\text { sustainable energy } \\
\text { sources selection. }\end{array}$ & $\begin{array}{l}\text { Economic dimension, } \\
\text { environmental dimension and } \\
\text { social dimension with sub- } \\
\text { criteria. }\end{array}$ & $\begin{array}{c}\text { sustainable } \\
\text { energy }\end{array}$ \\
\hline $\begin{array}{c}\text { Kurka and } \\
\text { Blackwood } \\
{[185]}\end{array}$ & 2013 & UK & $\begin{array}{c}\text { AHP, } \\
\text { DELTAP and } \\
\text { ROMETHEEII }\end{array}$ & $\begin{array}{l}\text { Selected the suitable } \\
\text { MCA method for } \\
\text { sustainability } \\
\text { energy systems. }\end{array}$ & $\begin{array}{l}\text { Measures to deal with } \\
\text { uncertainty, user friendliness and } \\
\text { flexibility, transparency and } \\
\text { communication and multi- } \\
\text { stakeholder inclusion. }\end{array}$ & $\begin{array}{c}\text { sustainable } \\
\text { energy }\end{array}$ \\
\hline $\begin{array}{l}\text { Datta, et al. } \\
\quad[186]\end{array}$ & 2014 & India & $\begin{array}{l}\text { ANP and } \\
\text { TOPSIS }\end{array}$ & $\begin{array}{l}\text { Integrated ANP and } \\
\text { TOPSIS for selection } \\
\text { of solar } \\
\text { photovoltaic system. }\end{array}$ & $\begin{array}{l}\text { Suitability for inverter based } \\
\text { DG, non-detectable zone, } \\
\text { implementation cost, suitability } \\
\text { for multi-DG systems, operating } \\
\text { time, degrading power quality } \\
\text { and reliability. }\end{array}$ & $\begin{array}{c}\text { sustainable } \\
\text { energy }\end{array}$ \\
\hline $\begin{array}{l}\text { Vafaeipour, } \\
\text { et al. }[187]\end{array}$ & 2014 & Iran & $\begin{array}{l}\text { SWARA and } \\
\text { WASPAS }\end{array}$ & $\begin{array}{l}\text { Employed SWARA } \\
\text { and WASPAS for } \\
\text { selection of region for } \\
\text { apply solar project. }\end{array}$ & $\begin{array}{l}\text { Risk, social, environmental, and } \\
\text { economic with sub-criteria. }\end{array}$ & $\begin{array}{c}\text { sustainable } \\
\text { energy }\end{array}$ \\
\hline $\begin{array}{c}\text { Ren and } \\
\text { Sovacool [188] }\end{array}$ & 2015 & Italy & $\begin{array}{l}\text { AHP and } \\
\text { TOPSIS }\end{array}$ & $\begin{array}{l}\text { Applied AHP and } \\
\text { TOPSIS for ranking of } \\
\text { low-carbon } \\
\text { energy sources. }\end{array}$ & $\begin{array}{l}\text { Technological maturity, resource } \\
\text { reliability, social acceptability, } \\
\text { government support and } \\
\text { energy security. }\end{array}$ & $\begin{array}{c}\text { sustainable } \\
\text { energy }\end{array}$ \\
\hline Ren, et al. [189] & 2009 & Japan & $\begin{array}{c}\text { AHP and } \\
\text { PROMETHEE }\end{array}$ & $\begin{array}{l}\text { Applied AHP and } \\
\text { PROMETHEE for } \\
\text { assessment of system } \\
\text { of sustainable } \\
\text { residential energy. }\end{array}$ & $\begin{array}{l}\mathrm{CO}_{2} \text { emissions, running cost, } \\
\text { primary energy consumption and } \\
\text { investment cost. }\end{array}$ & $\begin{array}{c}\text { sustainable } \\
\text { energy }\end{array}$ \\
\hline
\end{tabular}


Table 7. Cont.

\begin{tabular}{|c|c|c|c|c|c|c|}
\hline Author & Year & Nationality & $\begin{array}{c}\text { Technique } \\
\text { and } \\
\text { Application }\end{array}$ & Summary of Paper & Criteria & Area \\
\hline $\begin{array}{l}\text { Chung and Lee } \\
\text { [190] }\end{array}$ & 2009 & $\begin{array}{l}\text { Republic of } \\
\text { Korea }\end{array}$ & $\begin{array}{l}\text { ELECTRE II, } \\
\text { EVAMIX and } \\
\text { Regime }\end{array}$ & $\begin{array}{l}\text { Used ELECTRE II, } \\
\text { EVAMIX and Regime } \\
\text { for ranking of water } \\
\text { management criteria. }\end{array}$ & $\begin{array}{l}\text { Technical, environmental and } \\
\text { economic with criteria. }\end{array}$ & $\begin{array}{c}\text { sustainable } \\
\text { energy }\end{array}$ \\
\hline $\begin{array}{c}\text { Kaya and } \\
\text { Kahraman } \\
\text { [191] }\end{array}$ & 2010 & Turkey & $\begin{array}{l}\text { VIKOR and } \\
\text { AHP }\end{array}$ & $\begin{array}{l}\text { Applied VIKOR and } \\
\text { AHP for assessment } \\
\text { of renewable } \\
\text { energy planning. }\end{array}$ & $\begin{array}{l}\text { Technical criteria, economic } \\
\text { criteria, environmental criteria } \\
\text { and social criteria with nine sub- } \\
\text { criteria. }\end{array}$ & $\begin{array}{c}\text { renewable } \\
\text { energy }\end{array}$ \\
\hline $\begin{array}{c}\text { Yeh and Huang } \\
\text { [192] }\end{array}$ & 2014 & Taiwan & $\begin{array}{c}\text { Fuzzy } \\
\text { DEMATEL } \\
\text { and ANP }\end{array}$ & $\begin{array}{l}\text { Used for selection of } \\
\text { wind farm location. }\end{array}$ & $\begin{array}{l}\text { Safety and quality, economy and } \\
\text { benefit, social impression, } \\
\text { environment and ecology, } \\
\text { regulation and policy. }\end{array}$ & $\begin{array}{c}\text { sustainable } \\
\text { energy }\end{array}$ \\
\hline $\begin{array}{l}\text { Georgiou, et al. } \\
\text { [193] }\end{array}$ & 2015 & Greece & $\begin{array}{l}\text { PROMETHEE } \\
\text { and AHP }\end{array}$ & $\begin{array}{c}\text { Employed } \\
\text { PROMETHEE and } \\
\text { AHP for energy supply } \\
\text { configuration. }\end{array}$ & $\begin{array}{l}\text { Complexity, maturity, amount of } \\
\text { produced water, quality of } \\
\text { produced water and specific } \\
\text { energy consumption. }\end{array}$ & $\begin{array}{c}\text { renewable } \\
\text { energy }\end{array}$ \\
\hline
\end{tabular}

\subsection{Distribution of Papers Based on Name of Journal}

Table 8 provides the distribution based on the name of the journal which was used throughout the paper. The papers related to the MCDM techniques, and sustainable and renewable energy are distributed through 19 journals, which cover an extensive range of the "Web of Science" database. From these 19 journals, the first rank was the journal Renewable Energy, with 16 papers. This result indicates that this journal has the most significant role in MCDM issues and sustainable and renewable energy fields. Journal of Renewable and Sustainable Energy Reviews and Journal of Energy Policy had the second and third rank, with eight and five papers, respectively; in addition, Journal of Energy and Applied Energy, with three papers, had fourth and fifth rank. The frequency of other published journals is shown in Table 8 .

\subsection{Distribution of Papers Based on Publication Year}

Figure 5 presents important evidence based on the frequency of distribution by the year of publication. The results indicate that from 2003-2015 information about the use of MCDM techniques in sustainable and renewable energy areas has grown. According to the findings from this section, the use of these techniques and approaches in 2003 was found in only one paper, and this number increased to three papers in 2004; the number of publications increased to 10 and nine papers in 2014 and 2015, respectively. Accordingly, it can be indicated that researchers in different fields and categories of sustainable and renewable energy use MCDM techniques nowadays in their research, and it can be predicted that in coming years these numbers will increase. Results of publication years are shown in Figure 5. 
Table 8. Distribution of papers based on the name of journals.

\begin{tabular}{lcc}
\hline \multicolumn{1}{c}{ Name of Journal } & Number & Percentage (\%) \\
\hline Renewable Energy & 16 & $29.63 \%$ \\
Renewable and Sustainable Energy Reviews & 8 & $14.81 \%$ \\
Energy Conversion and Management & 5 & $9.26 \%$ \\
Energy Policy & 5 & $9.26 \%$ \\
Applied Energy & 3 & $5.56 \%$ \\
Energy & 3 & $5.56 \%$ \\
Construction and Building Materials & 2 & $3.70 \%$ \\
Automation in Construction & 1 & $1.85 \%$ \\
Building and Environment & 1 & $1.85 \%$ \\
Cities & 1 & $1.85 \%$ \\
Energy and Buildings & 1 & $1.85 \%$ \\
Energy Sources, Part B & 1 & $1.85 \%$ \\
International Journal of Computational Intelligence Systems & 1 & $1.85 \%$ \\
Journal of Business Economics and Management & 1 & $1.85 \%$ \\
Journal of Cleaner Production & 1 & $1.85 \%$ \\
Journal of Environmental Management & 1 & $1.85 \%$ \\
Solar Energy & 1 & $1.85 \%$ \\
Technological and Economic Development of Economy & 1 & $1.85 \%$ \\
Technological Forecasting and Social Change & 1 & $1.85 \%$ \\
\hline
\end{tabular}

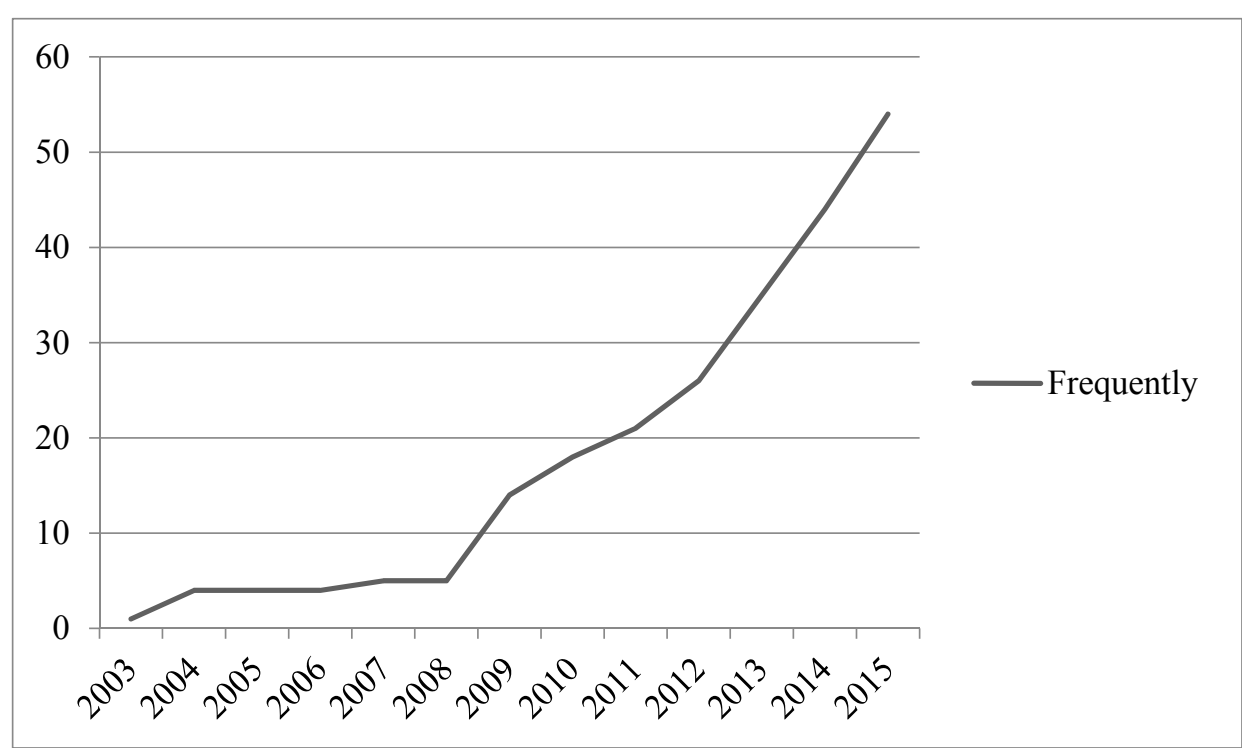

Figure 5. Distribution papers based on year of publication.

\subsection{Distribution of Papers Based on Nationality of Authors}

Table 9 shows that authors from 21 nationalities and countries applied MCDM issues in the sustainable and renewable energy areas. Most of the published papers were from Turkey (14.81\%). However, findings of this paper indicate that Greece, Taiwan and Taiwan have published papers regarding sustainable and renewable energy areas by using MCDM techniques. Table 9 presents details regarding the nationality of authors. 
Table 9. Distribution of papers based on the authors' nationality.

\begin{tabular}{ccc}
\hline Name of Country & Number & Percentage (\%) \\
\hline Turkey & 8 & $14.81 \%$ \\
Greece & 6 & $11.11 \%$ \\
Taiwan & 5 & $9.26 \%$ \\
United Kingdom & 4 & $7.41 \%$ \\
Italy & 4 & $7.41 \%$ \\
USA & 3 & $5.56 \%$ \\
Spain & 3 & $5.56 \%$ \\
Iran & 3 & $5.56 \%$ \\
Canada & 3 & $5.56 \%$ \\
Republic of Korea & 2 & $3.70 \%$ \\
Lithuania & 2 & $3.70 \%$ \\
India & 2 & $3.70 \%$ \\
Sweden & 1 & $1.85 \%$ \\
Sri Lanka & 1 & $1.85 \%$ \\
Romania & 1 & $1.85 \%$ \\
Oman & 1 & $1.85 \%$ \\
Japan & 1 & $1.85 \%$ \\
Germany & 1 & $1.85 \%$ \\
Estonia & 1 & $1.85 \%$ \\
Bosnia and Herzegovina & 1 & $1.85 \%$ \\
Australia & 1 & $1.85 \%$ \\
\hline
\end{tabular}

\section{Discussion}

The decision-making process determining the best energy alternative is multidimensional made up of a number of aspects at different levels, such as economic, technical, environmental, political and social. From this perspective, an MCDM approach to decision making appears to be the most appropriate tool to understand all the different perspectives involved, and to support those concerned with the decision-making process by creating a set of relationships between the various alternatives. Rational MCDM in energy system options, planning, management and economy is helpful to energy systems development. The growing diversity of MCDM techniques has prompted a number of reviews in recent years that have highlighted the strengths and weaknesses of these techniques in solving energy decision-making problems. In the real word, the decision-making problems are very vague and uncertain in a number of ways. Most criteria have interdependent and interactive features, so they cannot be evaluated by conventional measures. It would be more suitable to apply MCDM and fuzzy MCDM methods in energy systems problems to approximate the human subjective evaluation process.

Results obtained from this review show that MCDM approaches and techniques are appropriate for energy systems. This study shows that a large number of MCDM approaches and techniques exist and many of these methods are applicable to the solution of problems in the sustainable and renewable energies systems fields. Each approach and technique may have some drawbacks and advantages, and it cannot be claimed that a particular approach or technique is more suitable than the others. Various DMs generally disagree about which approach and technique is most valid and suitable. 
The selection of an approach and technique is mostly dependent upon the preferences of MCDM and the analyst. The methods must be taken into consideration in terms of validity, suitability and user-friendliness. In addition, it should be realized that employing different approaches and techniques most probably leads to different recommendations, and it is noteworthy that there may be errors in any approach or technique. This paper provided several examples of the way various MCDM approaches and techniques have been applied to the sustainable and renewable energies systems fields.

All the studies consider different aspects of the sustainable and renewable energies systems in various sub-areas with high planning levels, such as a regional or even national level. The techniques and approaches have been very widely used to take care of multiple, conflicting criteria to arrive at better solutions. Increasing popularity and applicability of these techniques and approaches beyond 1990 indicates a paradigm shift in energy systems fields. The techniques and approaches are observed to be most popular in the sustainable and renewable energies systems fields followed by two sub-areas, including sustainable energy and renewable energies areas. This study confirms that MCDM techniques can assist stakeholders and decision makers in unravelling some of the uncertainties inherent in environmental decision making, uncertainties that are borne out of the complexities of natural systems, a lack of sufficient data, a wide range of stakeholders and their associated objectives. The sustainable and renewable energies decision making reviewed in this study demonstrates a growing interest with previous scholars to apply these techniques for different stages of energy decision processes. MCDM approaches and techniques have been broadly employed to address multiple, conflicting criteria in a way to achieve better solutions. According to the findings of this review paper, it can be observed that efficiency of energy, power, capital investment, risk, quality, delivery, resources, flexibility, time, investment cost, $\mathrm{CO}_{2}$ emission, cultural, technology, climate change and government support are the most common criteria in the environmental, institutional, market, functional, political/legal, financial, technical, safety, ecological, social and economic attributes.

\section{Concluding Remarks}

This study was aimed to review papers that used the MCDM techniques in areas of sustainable and renewable energies and were published from 2003-2015 in popular international journals related to energy fields accessible in Web of Science databases. Moreover, this study attempted to classify papers into two main application areas: sustainable energy and renewable energy. In the field of sustainable energy, results indicated that 27 papers have employed MCDM techniques. In addition, in the field of renewable energy, findings indicated that 27 studies used MCDM techniques. Other information about this classification is presented in Table 1.

In the distribution of journals, Journal of Renewable Energy was the first ranked journal among 19 journals, with 16 published papers related to the MCDM techniques in fields of sustainable energy and renewable energy. In the nationality-based classification, it was shown that 21 nationalities and countries applied MCDM techniques. Finally, Turkey was shown to have the highest contribution to the publication of MCDM techniques, with eight papers.

The present paper has also some limitations and recommendations for future studies. First of all, this study categorized papers into two application areas. It is recommended for future studies to review papers in different sub-areas of these categories. The second limitation was that this study was mostly 
concentrated on English journals; that is, journals in other languages were not taken into consideration, although, the authors believe that this study has provided a comprehensive review and included the majority of high citation papers which have been published by journals on the sustainable energy and renewable energy fields. According to the objective of this review paper, we searched the keywords that directly related to renewable and sustainable energy, such as, sustainable energy, wind and solar energies, PV energy, renewable energies and MCDM techniques, in addition, in terms of fuzzy MCDM methods. This review paper attempted to select those papers which were more cited and viewed by other scholars mentioned in two databases, including Web of Science. This present paper focused more on 30 journals which most related to renewable and sustainable energy rather than all energy journals. Some of the papers relating to renewable and sustainable energy were review-based; therefore, we excluded these kinds of papers. The objective of this paper was to review papers related to MCDM techniques and renewable and sustainable energy rather than other energies topics. Some energy topics were published in doctoral dissertations, master's theses, textbooks, papers and unpublished papers, which were ignored in this review. This paper focused on the main academic database, including Web of Science, and due to limitation of access point, some papers related to renewable and sustainable energy were published in some other publications rather than Web of Science.

This review paper contributes to existing literature by demonstrating the possibility of combining decision making with sustainable energy and renewable energy problems. In an age of increasing globalization and increasing flows of information, decision makers and scientists are trying to better understand how to construct decision making systems to address a range of multi-level sustainable energy and renewable energy problems. Generally, MCDM methodologies have been used successfully in various applications and industrial sectors with different subjects and terms, although interdisciplinary and social decision problems should be further emphasized. Future study on the MCDM anatomy can be further developed. This study is hoped to be employed by academics and managers as a basis for further research, to help practitioners make more appropriate decisions using MCDM techniques in fields of sustainable energy and renewable energy and guide scholars to enhance these methodologies.

\section{Acknowledgments}

The authors wish to thank the Universiti Teknologi Malaysia (UTM), Vilnius Gediminas Technical University (VGTU) and University of Molise for their support.

\section{Author Contributions}

The individual contribution and responsibilities of the authors were as follows: Abbas Mardani and Ahmad Jusoh together designed research, Edmundas Kazimieras Zavadskas and Fausto Cavallaro provided extensive advice throughout the study regarding to research design, research methodology, findings and revise the manuscript. The discussion was a team task. Zainab Khalifah helped to draft, edit, and revise the manuscript. All authors have read and approved the final manuscript. 


\section{Conflicts of Interest}

The authors declare no conflict of interest.

\section{References}

1. Çelikler, D. Awareness about renewable energy of pre-service science teachers in Turkey. Renew. Energy 2013, 60, 343-348.

2. Kacan, E. Renewable energy awareness in vocational and technical education. Renew. Energy 2015, 76, 126-134.

3. Sapkota, A.; Lu, Z.; Yang, H.; Wang, J. Role of renewable energy technologies in rural communities' adaptation to climate change in Nepal. Renew. Energy 2014, 68, 793-800.

4. Sen, R.; Bhattacharyya, S.C. Off-grid electricity generation with renewable energy technologies in India: An application of HOMER. Renew. Energy 2014, 62, 388-398.

5. Effendi, P.; Courvisanos, J. Political aspects of innovation: Examining renewable energy in Australia. Renew. Energy 2012, 38, 245-252.

6. Alnaser, W.E.; Al-Kalak, A.; Al-Azraq, M.A.T. The efforts of the Arab League Education, Culture and Scientific Organization (ALECSO) in the field of renewable energy. Renew. Energy 1995, 6, 649-657.

7. Skoglund, A.; Leijon, M.; Rehn, A.; Lindahl, M.; Waters, R. On the physics of power, energy and economics of renewable electric energy sources - Part II. Renew. Energy 2010, 35, 1735-1740.

8. Leijon, M.; Skoglund, A.; Waters, R.; Rehn, A.; Lindahl, M. On the physics of power, energy and economics of renewable electric energy sources - Part I. Renew. Energy 2010, 35, 1729-1734.

9. Fouquet, D. Policy instruments for renewable energy-From a European perspective. Renew. Energy 2013, 49, 15-18.

10. Sun, P.; Nie, P.-Y. A comparative study of feed-in tariff and renewable portfolio standard policy in renewable energy industry. Renew. Energy 2015, 74, 255-262.

11. Akella, A.K.; Saini, R.P.; Sharma, M.P. Social, economical and environmental impacts of renewable energy systems. Renew. Energy 2009, 34, 390-396.

12. Zeb, R.; Salar, L.; Awan, U.; Zaman, K.; Shahbaz, M. Causal links between renewable energy, environmental degradation and economic growth in selected SAARC countries: Progress towards green economy. Renew. Energy 2014, 71, 123-132.

13. Davidsson, S.; Grandell, L.; Wachtmeister, H.; Höök, M. Growth curves and sustained commissioning modelling of renewable energy: Investigating resource constraints for wind energy. Energ. Policy 2014, 73, 767-776.

14. Malik, S.N.; Sukhera, O.R. Management of natural gas resources and search for alternative renewable energy resources: A case study of Pakistan. Renew. Sustain. Energy Rev. 2012, 16, 1282-1290.

15. Al-Karaghouli, A.; Kazmerski, L.L. Energy consumption and water production cost of conventional and renewable-energy-powered desalination processes. Renew. Sustain. Energy Rev. 2013, 24, 343-356. 
16. Oseni, M.O. Improving households' access to electricity and energy consumption pattern in Nigeria: Renewable energy alternative. Renew. Sustain. Energy Rev. 2012, 16, 3967-3974.

17. Yildirim, E.; Saraç, Ş.; Aslan, A. Energy consumption and economic growth in the USA: Evidence from renewable energy. Renew. Sustain. Energy Rev. 2012, 16, 6770-6774.

18. Arent, D.; Pless, J.; Mai, T.; Wiser, R.; Hand, M.; Baldwin, S.; Heath, G.; Macknick, J.; Bazilian, M.; Schlosser, A.; et al. Implications of high renewable electricity penetration in the U.S. for water use, greenhouse gas emissions, land-use, and materials supply. Appl. Energy 2014, 123, 368-377.

19. Li, X.; Feng, K.; Siu, Y.L.; Hubacek, K. Energy-water nexus of wind power in China: The balancing act between CO2 emissions and water consumption. Energ. Policy 2012, 45, 440-448.

20. Abdullah, M.A.; Agalgaonkar, A.P.; Muttaqi, K.M. Climate change mitigation with integration of renewable energy resources in the electricity grid of New South Wales, Australia. Renew. Energy 2014, 66, 305-313.

21. Girod, B.; van Vuuren, D.P.; Hertwich, E.G. Climate policy through changing consumption choices: Options and obstacles for reducing greenhouse gas emissions. Glob. Environ. Chang. 2014, 25, 5-15.

22. Monstadt, J.; Scheiner, S. Allocating greenhouse gas emissions in the German federal system: Regional interests and federal climate governance. Energy Policy 2014, 74, 383-394.

23. Peterson, A.T.; Scachetti-Pereira, R.; Kluza, D.A. Assessment of invasive potential of Homalodisca coagulata in western North America and South America. Biota Neotropica 2003, 3, 1-7.

24. Kowalski, K.; Stagl, S.; Madlener, R.; Omann, I. Sustainable energy futures: Methodological challenges in combining scenarios and participatory multi-criteria analysis. Eur. J. Oper. Res. 2009, 197, 1063-1074.

25. Karger, C.R.; Hennings, W. Sustainability evaluation of decentralized electricity generation. Renew. Sustain. Energy Rev. 2009, 13, 583-593.

26. Del Rio, P.; Burguillo, M. Assessing the impact of renewable energy deployment on local sustainability: Towards a theoretical framework. Renew. Sustain. Energy Rev. 2008, 12, 1325-1344.

27. Kemp, R. Sustainable Technologies Do Not Exist. Available online: http://www.researchgate.net/ profile/Rene_Kemp/publication/227351480_Sustainable_technologies_do_not_exist!/links/0a85e 534ce87ce95cb000000.pdf (accessed on 13 October 2015).

28. Brent, A.C.; Rogers, D.E. Renewable rural electrification: Sustainability assessment of mini-hybrid off-grid technological systems in the African context. Renew. Energy 2010, 35, 257-265.

29. Madlener, R.; Antunes, C.H.; Dias, L.C. Assessing the performance of biogas plants with multi-criteria and data envelopment analysis. Eur. J. Oper. Res. 2009, 197, 1084-1094.

30. Mallikarjun, S.; Lewis, H.F. Energy technology allocation for distributed energy resources: A strategic technology-policy framework. Energy 2014, 72, 783-799.

31. Önüt, S.; Tuzkaya, U.R.; Saadet, N. Multiple criteria evaluation of current energy resources for Turkish manufacturing industry. Energy Convers. Manag. 2008, 49, 1480-1492.

32. Georgopoulou, E.; Sarafidis, Y.; Diakoulaki, D. Design and implementation of a group DSS for sustaining renewable energies exploitation. Eur. J. Oper. Res. 1998, 109, 483-500. 
33. Kablan, M.M. Decision support for energy conservation promotion: An analytic hierarchy process approach. Energy Policy 2004, 32, 1151-1158.

34. Wang, E. Benchmarking whole-building energy performance with multi-criteria technique for order preference by similarity to ideal solution using a selective objective-weighting approach. Appl. Energy 2015, 146, 92-103.

35. Bilişik, Ö.N.; Erdoğan, M.; Kaya, İ.; Baraçlı, H. A hybrid fuzzy methodology to evaluate customer satisfaction in a public transportation system for Istanbul. Total Qual. Manag. Bus. Excell. 2013, 24, 1141-1159.

36. Sadi-Nezhad, S.; Damghani, K.K. A modified TOPSIS technique in presence of uncertainty and its application to assessment of transportation systems. Int. J. Manag. Sci. Eng. Manag. 2011, $6,3-13$.

37. Wang, J.-J.; Jing, Y.-Y.; Zhang, C.-F.; Zhao, J.-H. Review on multi-criteria decision analysis aid in sustainable energy decision-making. Renew. Sustain. Energy Rev. 2009, 13, 2263-2278.

38. Pohekar, S.; Ramachandran, M. Application of multi-criteria decision making to sustainable energy planning-A review. Renew. Sustain. Energy Rev. 2004, 8, 365-381.

39. Gyamfi, S.; Modjinou, M.; Djordjevic, S. Improving electricity supply security in Ghana-The potential of renewable energy. Renew. Sustain. Energy Rev. 2015, 43, 1035-1045.

40. Shen, J.; Luo, C. Overall review of renewable energy subsidy policies in China-Contradictions of intentions and effects. Renew. Sustain. Energy Rev. 2015, 41, 1478-1488.

41. Beccali, M.; Cellura, M.; Mistretta, M. Environmental effects of energy policy in sicily: The role of renewable energy. Renew. Sustain. Energy Rev. 2007, 11, 282-298.

42. Kim, K.; Kim, Y. Role of policy in innovation and international trade of renewable energy technology: Empirical study of solar PV and wind power technology. Renew. Sustain. Energy Rev. 2015, 44, 717-727.

43. Milosavljević, D.D.; Pavlović, T.M.; Piršl, D.S. Performance analysis of A grid-connected solar PV plant in Niš, republic of Serbia. Renew. Sustain. Energy Rev. 2015, 44, 423-435.

44. Zhang, S.; Zhao, X.; Andrews-Speed, P.; He, Y. The development trajectories of wind power and solar PV power in China: A comparison and policy recommendations. Renew. Sustain. Energy Rev. 2013, 26, 322-331.

45. Talaei, A.; Ahadi, M.S.; Maghsoudy, S. Climate friendly technology transfer in the energy sector: A case study of Iran. Energy Policy 2014, 64, 349-363.

46. Chaiamarit, K.; Nuchprayoon, S. Impact assessment of renewable generation on electricity demand characteristics. Renew. Sustain. Energy Rev. 2014, 39, 995-1004.

47. Cong, R.-G. An optimization model for renewable energy generation and its application in China: A perspective of maximum utilization. Renew. Sustain. Energy Rev. 2013, 17, 94-103.

48. Villasevil, F.X.; Vigara, J.E.; Chiarle, L. Plug-in driven architecture for renewable energy generation monitoring. Renew. Sustain. Energy Rev. 2013, 27, 401-406.

49. Zeng, M.; Duan, J.; Wang, L.; Zhang, Y.; Xue, S. Orderly grid connection of renewable energy generation in China: Management mode, existing problems and solutions. Renew. Sustain. Energy Rev. 2015, 41, 14-28. 
50. Zhang, M.; Zhou, D.; Zhou, P. A real option model for renewable energy policy evaluation with application to solar PV power generation in China. Renew. Sustain. Energy Rev. 2014, 40, 944-955.

51. Alotto, P.; Guarnieri, M.; Moro, F. Redox flow batteries for the storage of renewable energy: A review. Renew. Sustain. Energy Rev. 2014, 29, 325-335.

52. Chakrabarti, M.H.; Mjalli, F.S.; AlNashef, I.M.; Hashim, M.A.; Hussain, M.A.; Bahadori, L.; Low, C.T.J. Prospects of applying ionic liquids and deep eutectic solvents for renewable energy storage by means of redox flow batteries. Renew. Sustain. Energy Rev. 2014, 30, 254-270.

53. Evans, A.; Strezov, V.; Evans, T.J. Assessment of utility energy storage options for increased renewable energy penetration. Renew. Sustain. Energy Rev. 2012, 16, 4141-4147.

54. Yekini Suberu, M.; Wazir Mustafa, M.; Bashir, N. Energy storage systems for renewable energy power sector integration and mitigation of intermittency. Renew. Sustain. Energy Rev. 2014, 35, 499-514.

55. Connolly, D.; Lund, H.; Mathiesen, B.V.; Pican, E.; Leahy, M. The technical and economic implications of integrating fluctuating renewable energy using energy storage. Renew. Energy 2012, 43, 47-60.

56. Gude, V.G. Energy storage for desalination processes powered by renewable energy and waste heat sources. Appl. Energy 2015, 137, 877-898.

57. Mills, A.; Phadke, A.; Wiser, R. Exploration of resource and transmission expansion decisions in the Western Renewable Energy Zone initiative. Energ. Policy 2011, 39, 1732-1745.

58. Saguan, M.; Meeus, L. Impact of the regulatory framework for transmission investments on the cost of renewable energy in the EU. Energy Econ. 2014, 43, 185-194.

59. Wright, G. Facilitating efficient augmentation of transmission networks to connect renewable energy generation: The Australian experience. Energy Policy 2012, 44, 79-91.

60. Auld, T.; McHenry, M.P.; Whale, J.U.S. Military, airspace, and meteorological radar system impacts from utility class wind turbines: Implications for renewable energy targets and the wind industry. Renew. Energy 2013, 55, 24-30.

61. Benson, C.L.; Magee, C.L. On improvement rates for renewable energy technologies: Solar PV, wind turbines, capacitors, and batteries. Renew. Energy 2014, 68, 745-751.

62. Kolhe, M.; Agbossou, K.; Hamelin, J.; Bose, T.K. Analytical model for predicting the performance of photovoltaic array coupled with a wind turbine in a stand-alone renewable energy system based on hydrogen. Renew. Energy 2003, 28, 727-742.

63. Liu, S.-Y.; Perng, Y.-H.; Ho, Y.-F. The effect of renewable energy application on Taiwan buildings: What are the challenges and strategies for solar energy exploitation? Renew. Sustain. Energy Rev. 2013, 28, 92-106.

64. Chen, L.; Xing, L.; Han, L. Renewable energy from agro-residues in China: Solid biofuels and biomass briquetting technology. Renew. Sustain. Energy Rev. 2009, 13, 2689-2695.

65. Montuori, L.; Alcázar-Ortega, M.; Álvarez-Bel, C.; Domijan, A. Integration of renewable energy in microgrids coordinated with demand response resources: Economic evaluation of a biomass gasification plant by Homer Simulator. Appl. Energy 2014, 132, 15-22.

66. Kaldellis, J.K.; Kapsali, M.; Kaldelli, E.; Katsanou, E. Comparing recent views of public attitude on wind energy, photovoltaic and small hydro applications. Renew. Energy 2013, 52, 197-208. 
67. Montes, G.M.; del Mar Serrano López, M.; del Carmen Rubio Gámez, M.; Ondina, A.M. An overview of renewable energy in Spain. The small hydro-power case. Renew. Sustain. Energy Rev. 2005, 9, 521-534.

68. Sharma, R.C.; Bisht, Y.; Sharma, R.; Singh, D. Gharats (watermills): Indigenous device for sustainable development of renewable hydro-energy in Uttrakhand Himalayas. Renew. Energy 2008, 33, 2199-2206.

69. Carley, S. State renewable energy electricity policies: An empirical evaluation of effectiveness. Energy Policy 2009, 37, 3071-3081.

70. Jenner, S.; Groba, F.; Indvik, J. Assessing the strength and effectiveness of renewable electricity feed-in tariffs in European Union countries. Energy Policy 2013, 52, 385-401.

71. Shrimali, G.; Kniefel, J. Are government policies effective in promoting deployment of renewable electricity resources? Energy Policy 2011, 39, 4726-4741.

72. Yin, H.; Powers, N. Do state renewable portfolio standards promote in-state renewable generation? Energy Policy 2010, 38, 1140-1149.

73. Marques, A.C.; Fuinhas, J.A. Is renewable energy effective in promoting growth? Energy Policy 2012, 46, 434-442.

74. Apergis, N.; Payne, J.E. Renewable energy consumption and economic growth: Evidence from a panel of OECD countries. Energy Policy 2010, 38, 656-660.

75. Marques, A.C.; Fuinhas, J.A. Are public policies towards renewables successful? Evidence from European countries. Renew. Energy 2012, 44, 109-118.

76. Luthra, S.; Kumar, S.; Garg, D.; Haleem, A. Barriers to renewable/sustainable energy technologies adoption: Indian perspective. Renew. Sustain. Energy Rev. 2015, 41, 762-776.

77. Streimikiene, D.; Balezentis, T.; Krisciukaitienè, I.; Balezentis, A. Prioritizing sustainable electricity production technologies: MCDM approach. Renew. Sustain. Energy Rev. 2012, 16, 3302-3311.

78. Van de Kaa, G.; Rezaei, J.; Kamp, L.; de Winter, A. Photovoltaic technology selection: A fuzzy MCDM approach. Renew. Sustain. Energy Rev. 2014, 32, 662-670.

79. Shen, Y.-C.; Lin, G.T.; Li, K.-P.; Yuan, B.J. An assessment of exploiting renewable energy sources with concerns of policy and technology. Energy Policy 2010, 38, 4604-4616.

80. Zhao, H.; Guo, S. External Benefit Evaluation of Renewable Energy Power in China for Sustainability. Sustainability 2015, 7, 4783-4805.

81. Zhao, H.; Guo, S. Selecting green supplier of thermal power equipment by using a hybrid mcdm method for sustainability. Sustainability 2014, 6, 217-235.

82. Stein, E.W. A comprehensive multi-criteria model to rank electric energy production technologies. Renew. Sustain. Energy Rev. 2013, 22, 640-654.

83. Doukas, H.C.; Andreas, B.M.; Psarras, J.E. Multi-criteria decision aid for the formulation of sustainable technological energy priorities using linguistic variables. Eur. J. Oper. Res. 2007, 182, 844-855.

84. Balezentiene, L.; Streimikiene, D.; Balezentis, T. Fuzzy decision support methodology for sustainable energy crop selection. Renew. Sustain. Energy Rev. 2013, 17, 83-93.

85. Oberschmidt, J.; Geldermann, J.; Ludwig, J.; Schmehl, M. Modified PROMETHEE approach for assessing energy technologies. Int. J. Energy Sect. Manag. 2010, 4, 183-212. 
86. Zangeneh, A.; Jadid, S.; Rahimi-Kian, A. A hierarchical decision making model for the prioritization of distributed generation technologies: A case study for Iran. Energy Policy 2009, 37, 5752-5763.

87. Ren, J.; Fedele, A.; Mason, M.; Manzardo, A.; Scipioni, A. Fuzzy Multi-actor Multi-criteria Decision Making for sustainability assessment of biomass-based technologies for hydrogen production. Int. J. Hydrogen Energy 2013, 38, 9111-9120.

88. Troldborg, M.; Heslop, S.; Hough, R.L. Assessing the sustainability of renewable energy technologies using multi-criteria analysis: Suitability of approach for national-scale assessments and associated uncertainties. Renew. Sustain. Energy Rev. 2014, 39, 1173-1184.

89. Havlíčková, K.; Suchý, J. Development model for energy crop plantations in the Czech Republic for the years 2008-2030. Renew. Sustain. Energy Rev. 2010, 14, 1925-1936.

90. Đatkov, Đ.; Effenberger, M. Data envelopment analysis for assessing the efficiency of biogas plants: Capabilities and limitations. J. Process. Energy Agric. 2010, 14, 49-53.

91. Evans, A.; Strezov, V.; Evans, T.J. Assessment of sustainability indicators for renewable energy technologies. Renew. Sustain. Energy Rev. 2009, 13, 1082-1088.

92. Beccali, M.; Cellura, M.; Mistretta, M. Decision-making in energy planning. Application of the Electre method at regional level for the diffusion of renewable energy technology. Renew. Energy 2003, 28, 2063-2087.

93. Browne, D.; O’Regan, B.; Moles, R. Use of multi-criteria decision analysis to explore alternative domestic energy and electricity policy scenarios in an Irish city-region. Energy 2010, 35, 518-528.

94. Burton, J.; Hubacek, K. Is small beautiful? A multicriteria assessment of small-scale energy technology applications in local governments. Energy Policy 2007, 35, 6402-6412.

95. Tsoutsos, T.; Drandaki, M.; Frantzeskaki, N.; Iosifidis, E.; Kiosses, I. Sustainable energy planning by using multi-criteria analysis application in the island of Crete. Energy Policy 2009, 37, 1587-1600.

96. Chatzimouratidis, A.I.; Pilavachi, P.A. Multicriteria evaluation of power plants impact on the living standard using the analytic hierarchy process. Energy Policy 2008, 36, 1074-1089.

97. Belton, V.; Stewart, T. Multiple Criteria decision Analysis: An Integrated Approach; Springer Science \& Business Media: Berlin, Germany; Heidelberg, Germany, 2002.

98. Greco, S.; Matarazzo, B.; Słowiński, R. Axiomatic characterization of a general utility function and its particular cases in terms of conjoint measurement and rough-set decision rules. Eur. J. Oper. Res. 2004, 158, 271-292.

99. Keeney, R.L.; Raiffa, H. Decisions with Multiple Objectives: Preferences and Value Trade-offs. Cambridge University Press: Cambridge, UK, 1993.

100. Roy, B. The outranking approach and the foundations of ELECTRE methods. Theory Decis. 1991, 31, 49-73.

101. Greco, S.; Matarazzo, B.; Slowinski, R. Rough Set Approach to Decisions under Risk. In Rough Sets and Current Trends in Computing; Ziarko, W., Yao, Y., Eds.; Springer: Berlin, Germany; Heidelberg, Germany, 2001; pp. 160-169.

102. Kaya, T.; Kahraman, C. An integrated fuzzy AHP-ELECTRE methodology for environmental impact assessment. Expert Syst. Appl. 2011, 38, 8553-8562. 
103. Gilbuena, R.; Kawamura, A.; Medina, R.; Nakagawa, N.; Amaguchi, H. Environmental impact assessment using a utility-based recursive evidential reasoning approach for structural flood mitigation measures in Metro Manila, Philippines. J. Environ. Manag. 2013, 131, 92-102.

104. Wang, P.; Lassoie, J.P.; Dong, S.; Morreale, S.J. A framework for social impact analysis of large dams: A case study of cascading dams on the Upper-Mekong River, China. J. Environ. Manag. 2013, 117, 131-140.

105. Ji, U.; Velleux, M.; Julien, P.Y.; Hwang, M. Risk assessment of watershed erosion at Naesung Stream, South Korea. J. Environ. Manag. 2014, 136, 16-26.

106. Hjaila, K.; Baccar, R.; Sarrà, M.; Gasol, C.; Blánquez, P. Environmental impact associated with activated carbon preparation from olive-waste cake via life cycle assessment. J. Environ. Manag. 2013, 130, 242-247.

107. Moss, T. The governance of land use in river basins: Prospects for overcoming problems of institutional interplay with the EU Water Framework Directive. Land Use Policy 2004, 21, 85-94.

108. Wiecek, M.M.; Ehrgott, M.; Fadel, G.; Rui Figueira, J. Multiple criteria decision making for engineering. Omega 2008, 36, 337-339.

109. Xu, Z.; Da, Q. The ordered weighted geometric averaging operators. Int. J. Intell. Syst. 2002, 17, 709-716.

110. Wang, Y.; Lee, H.; Lin, K. Fuzzy TOPSIS for multi-criteria decision-making. Int. Math. J. 2003, 3, 367-379.

111. Mardani, A.; Jusoh, A.; Zavadskas, E.K. Fuzzy multiple criteria decision-making techniques and applications-Two decades review from 1994 to 2014. Expert Syst. Appl. 2015, 42, 4126-4148.

112. MacCrimmon, K.R. Decisionmaking among Multiple-Attribute Alternatives: A Survey and Consolidated Approach; DTIC Document: Fort Belvoir, VA, USA, 1968.

113. Keeney, R.L.; Raiffa, H. Decision Analysis with Multiple Conflicting Objectives; Wiley\& Sons: New York, NY, USA, 1976.

114. Zavadskas, E.K.; Turskis, Z.; Antucheviciene, J.; Zakarevicius, A. Optimization of weighted aggregated sum product assessment. Elektron. Elektrotech. 2012, 122, 3-6.

115. Hwang, C.; Yoon, K. Multiple Attribute Decision Making: Methods and Applications, a State of the Art Survey. In Lecture Notes in Economics and Mathematical Systems 186; Springer-Verlag: Berlin, Germany; New York, NY, USA, 1981.

116. Opricovic, S.; Tzeng, G.-H. Compromise solution by MCDM methods: A comparative analysis of VIKOR and TOPSIS. Eur. J. Oper. Res. 2004, 156, 445-455.

117. Zavadskas, E.K.; Kaklauskas, A.; Sarka, V. The new method of multicriteria complex proportional assessment of projects. Technol. Econ. Dev. Econ. 1994, 1, 131-139.

118. Brauers, W.K.M.; Zavadskas, E.K. The MOORA method and its application to privatization in a transition economy. Control Cybern. 2006, 35, 445-469.

119. Brauers, W.K.M.; Zavadskas, E.K. Project management by MULTIMOORA as an instrument for transition economies. Technol. Econ. Dev. Econ. 2010, 16, 5-24.

120. Zavadskas, E.K.; Turskis, Z. A new logarithmic normalization method in games theory. Informatica 2008, 19, 303-314. 
121. Turskis, Z.; Zavadskas, E.K. A new fuzzy additive ratio assessment method (ARAS-F). Case study: The analysis of fuzzy multiple criteria in order to select the logistic centers location. Transport 2010, 25, 423-432.

122. Krylovas, A.; Zavadskas, E.K.; Kosareva, N.; Dadelo, S. New KEMIRA Method for Determining Criteria Priority and Weights in Solving MCDM Problem. Int. J. Inf. Technol. Decis. Mak. 2014, 13, 1119-1133.

123. Keršuliene, V.; Zavadskas, E.K.; Turskis, Z. Selection of rational dispute resolution method by applying new step-wise weight assessment ratio analysis (Swara). J. Bus. Econ. Manag. 2010, 11, 243-258.

124. Zavadskas, E.K.; Turskis, Z. A new additive ratio assessment (ARAS) method in multicriteria decision-making. Technol. Econ. Dev. Econ. 2010, 16, 159-172.

125. Yager, R.R. Aggregation operators and fuzzy systems modeling. Fuzzy Sets Syst. 1994, 67, 129-145.

126. Mareschal, B.; Brans, J.P. PROMETHEE V: MCDM Problems with Segmentation Constraints; ULB-Universite Libre de Bruxelles: Brussels, Belgium, 1992.

127. Roy, B. Multicriteria Methodology for Decision Aiding; Springer: Berlin, Germany; Heidelberg, Germany, 1996.

128. Munda, G. Multicriteria Evaluation in a Fuzzy Environment. Theory and Applications in Ecological Economics; Springer: Berlin, Germany; Heidelberg, Germany, 1998.

129. Saaty, T.L. What is the Analytic Hierarchy Process? Springer: Berlin, Germany; Heidelberg, Germany, 1988.

130. Saaty, R.W. Decision Making in Complex Environment: The Analytic Hierarchy Process (AHP) for Decision Making and the Analytic Network Process (ANP) for Decision Making with Dependence and Feedback; Super Decisions: Pittsburgh, PA, USA, 2003.

131. Saaty, T.L. Theory and Applications of the Analytic Network Process: Decision Making with Benefits, Opportunities, Costs, and Risks; RWS Publications: Pittsburgh, PA, USA, 2005.

132. Saaty, T.L.; Vargas, L.G. Decision Making with the Analytic Network Process; Springer: Berlin, Germany; Heidelberg, Germany, 2006.

133. Liou, J.J.; Tzeng, G.-H. Comments on "Multiple criteria decision making (MCDM) methods in economics: An overview". Technol. Econ. Dev. Econ. 2012, 18, 672-695.

134. Turskis, Z.; Zavadskas, E.K. Multiple criteria decision making (MCDM) methods in economics: An overview. Technol. Econ. Dev. Econ. 2011, 17, 397-427.

135. Mardani, A.; Jusoh, A.; Md Nor, K.; Khalifah, Z.; Zakwan, N.; Valipour, A. Multiple criteria decision-making techniques and their applications-a review of the literature from 2000 to 2014. Econ. Res. Ekon. Istraž. 2015, 28, 516-571.

136. Bellman, R.E.; Zadeh, L.A. Decision-making in a fuzzy environment. Manag. Sci. 1970, 17, B-141-B-164.

137. Zimmermann, H.-J. Fuzzy programming and linear programming with several objective functions. Fuzzy Sets Syst. 1978, 1, 45-55.

138. Yager, R.R. Fuzzy decision making including unequal objectives. Fuzzy Sets Syst. 1978, 1, 87-95. 
139. Kickert, W.J. Fuzzy Theories on Decision Making: A Critical Review; Springer: Berlin, Germany; Heidelberg, Germany, 1978.

140. Zavadskas, E.K.; Turskis, Z.; Kildiene, S. State of art surveys of overviews on MCDM/MADM methods. Technol. Econ. Dev. Econ. 2014, 20, 165-179.

141. Köksalan, M.M.; Wallenius, J.; Zionts, S. Multiple Criteria Decision Making: From Early History to the 21st Century; World Scientific: Singapore, Singapore, 2011.

142. Keeney, R.L.; Raiffa, H.; Rajala, D.W. Decisions with multiple objectives: Preferences and value trade-offs. IEEE Trans. Syst. Man Cybern. 1979, 9, 403-403.

143. Hwang, C.-L.; Masud, A.S.M.; Paidy, S.R.; Yoon, K.P. Multiple Objective Decision Making, Methods and Applications: A State-of-the-Art Survey; Springer: Berlin, Germany, 1979.

144. T Tzeng, G.-H.; Huang, J.-J. Multiple Attribute Decision Making: Methods and Applications; CRC Press: Boca Raton, FL, USA, 2011.

145. Heo, E.; Kim, J.; Boo, K.-J. Analysis of the assessment factors for renewable energy dissemination program evaluation using fuzzy AHP. Renew. Sustain. Energy Rev. 2010, 14, 2214-2220.

146. Davoudpour, H.; Rezaee, S.; Ashrafi, M. Developing a framework for renewable technology portfolio selection: A case study at a R\&amp; D center. Renew. Sustain. Energy Rev. 2012, 16, 4291-4297.

147. Ertay, T.; Kahraman, C.; Kaya, İ. Evaluation of renewable energy alternatives using MACBETH and fuzzy AHP multicriteria methods: The case of Turkey. Technol. Econ. Dev. Econ. 2013, $19,38-62$.

148. Karaca, F.; Raven, P.G.; Machell, J.; Camci, F. A comparative analysis framework for assessing the sustainability of a combined water and energy infrastructure. Technol. Forecast. Soc. Chang. 2015, 90, 456-468.

149. Pons, O.; Aguado, A. Integrated value model for sustainable assessment applied to technologies used to build schools in Catalonia, Spain. Build. Environ. 2012, 53, 49-58.

150. Kahraman, C.; Kaya, İ.; Cebi, S. A comparative analysis for multiattribute selection among renewable energy alternatives using fuzzy axiomatic design and fuzzy analytic hierarchy process. Energy 2009, 34, 1603-1616.

151. Reza, B.; Sadiq, R.; Hewage, K. Sustainability assessment of flooring systems in the city of Tehran: An AHP-based life cycle analysis. Construct. Build. Mater. 2011, 25, 2053-2066.

152. Pons, O.; de la Fuente, A. Integrated sustainability assessment method applied to structural concrete columns. Construct. Build. Mater. 2013, 49, 882-893.

153. Aras, H.; Erdoğmuş, Ş.; Koç, E. Multi-criteria selection for a wind observation station location using analytic hierarchy process. Renew. Energy 2004, 29, 1383-1392.

154. Nigim, K.; Munier, N.; Green, J. Pre-feasibility MCDM tools to aid communities in prioritizing local viable renewable energy sources. Renew. Energy 2004, 29, 1775-1791.

155. Lee, A.H.; Chen, H.H.; Kang, H.-Y. Multi-criteria decision making on strategic selection of wind farms. Renew. Energy 2009, 34, 120-126.

156. Al-Yahyai, S.; Charabi, Y.; Gastli, A.; Al-Badi, A. Wind farm land suitability indexing using multi-criteria analysis. Renew. Energy 2012, 44, 80-87. 
157. Peterseim, J.H.; White, S.; Tadros, A.; Hellwig, U. Concentrated solar power hybrid plants, which technologies are best suited for hybridisation? Renew. Energy 2013, 57, 520-532.

158. San Cristóbal, J.R. Multi-criteria decision-making in the selection of a renewable energy project in Spain: The Vikor method. Renew. Energy 2011, 36, 498-502.

159. Vučijak, B.; Kupusović, T.; Midžić-Kurtagić, S.; Ćerić, A. Applicability of multicriteria decision aid to sustainable hydropower. Appl. Energy 2013, 101, 261-267.

160. Cannemi, M.; García-Melón, M.; Aragonés-Beltrán, P.; Gómez-Navarro, T. Modeling decision making as a support tool for policy making on renewable energy development. Energy Policy 2014, 67, 127-137.

161. Shiue, Y.-C.; Lin, C.-Y. Applying analytic network process to evaluate the optimal recycling strategy in upstream of solar energy industry. Energy Build. 2012, 54, 266-277.

162. Kabak, M.; Dağdeviren, M. Prioritization of renewable energy sources for Turkey by using a hybrid MCDM methodology. Energy Convers. Manag. 2014, 79, 25-33.

163. Doukas, H.; Psarras, J. A linguistic decision support model towards the promotion of renewable energy. Energy Sources 2009, 4, 166-178.

164. Cavallaro, F. Fuzzy TOPSIS approach for assessing thermal-energy storage in concentrated solar power (CSP) systems. Appl. Energy 2010, 87, 496-503.

165. Perera, A.T.D.; Attalage, R.A.; Perera, K.K.C.K.; Dassanayake, V.P.C. A hybrid tool to combine multi-objective optimization and multi-criterion decision making in designing standalone hybrid energy systems. Appl. Energy 2013, 107, 412-425.

166. Kucukvar, M.; Gumus, S.; Egilmez, G.; Tatari, O. Ranking the sustainability performance of pavements: An intuitionistic fuzzy decision making method. Autom. Constr. 2014, 40, 33-43.

167. Lozano-Minguez, E.; Kolios, A.J.; Brennan, F.P. Multi-criteria assessment of offshore wind turbine support structures. Renew. Energy 2011, 36, 2831-2837.

168. Şengül, Ü.; Eren, M.; Eslamian Shiraz, S.; Gezder, V.; Şengül, A.B. Fuzzy TOPSIS method for ranking renewable energy supply systems in Turkey. Renew. Energy 2015, 75, 617-625.

169. Haralambopoulos, D.; Polatidis, H. Renewable energy projects: Structuring a multi-criteria group decision-making framework. Renew. Energy 2003, 28, 961-973.

170. Mohamadabadi, H.S.; Tichkowsky, G.; Kumar, A. Development of a multi-criteria assessment model for ranking of renewable and non-renewable transportation fuel vehicles. Energy 2009, 34, 112-125.

171. Pohekar, S.; Ramachandran, M. Multi-criteria evaluation of cooking energy alternatives for promoting parabolic solar cooker in India. Renew. Energy 2004, 29, 1449-1460.

172. Cavallaro, F. Multi-criteria decision aid to assess concentrated solar thermal technologies. Renew. Energy 2009, 34, 1678-1685.

173. Chang, C.-T. Multi-choice goal programming model for the optimal location of renewable energy facilities. Renew. Sustain. Energy Rev. 2015, 41, 379-389.

174. Buchholz, T.; Rametsteiner, E.; Volk, T.A.; Luzadis, V.A. Multi criteria analysis for bioenergy systems assessments. Energy Policy 2009, 37, 484-495.

175. Santoyo-Castelazo, E.; Azapagic, A. Sustainability assessment of energy systems: Integrating environmental, economic and social aspects. J. Clean. Product. 2014, 80, 119-138. 
176. Mainali, B.; Silveira, S. Using a sustainability index to assess energy technologies for rural electrification. Renew. Sustain. Energy Rev. 2015, 41, 1351-1365.

177. Patlitzianas, K.D.; Ntotas, K.; Doukas, H.; Psarras, J. Assessing the renewable energy producers' environment in EU accession member states. Energy Convers. Manag. 2007, 48, 890-897.

178. Aydin, N.Y.; Kentel, E.; Sebnem Duzgun, H. GIS-based site selection methodology for hybrid renewable energy systems: A case study from western Turkey. Energy Convers. Manag. 2013, 70, 90-106.

179. Egilmez, G.; Gumus, S.; Kucukvar, M. Environmental sustainability benchmarking of the U.S. and Canada metropoles: An expert judgment-based multi-criteria decision making approach. Cities 2015, 42, 31-41.

180. Nuuter, T.; Lill, I.; Tupenaite, L. Comparison of housing market sustainability in European countries based on multiple criteria assessment. Land Use Policy 2015, 42, 642-651.

181. Sánchez-Lozano, J.M.; Henggeler Antunes, C.; García-Cascales, M.S.; Dias, L.C. GIS-based photovoltaic solar farms site selection using ELECTRE-TRI: Evaluating the case for Torre Pacheco, Murcia, Southeast of Spain. Renew. Energy 2014, 66, 478-494.

182. Latinopoulos, D.; Kechagia, K. A GIS-based multi-criteria evaluation for wind farm site selection. A regional scale application in Greece. Renew. Energy 2015, 78, 550-560.

183. Yazdani-Chamzini, A.; Fouladgar, M.M.; Zavadskas, E.K.; Moini, S.H.H. Selecting the optimal renewable energy using multi criteria decision making. J. Bus. Econ. Manag. 2013, 14, 957-978.

184. Kuleli Pak, B.; Albayrak, Y.E.; Erensal, Y.C. Renewable energy perspective for Turkey using sustainability indicators. Int. J. Comput. Intell. Syst. 2015, 8, 187-197.

185. Kurka, T.; Blackwood, D. Selection of MCA methods to support decision making for renewable energy developments. Renew. Sustain. Energy Rev. 2013, 27, 225-233.

186. Datta, A.; Saha, D.; Ray, A.; Das, P. Anti-islanding selection for grid-connected solar photovoltaic system applications: A MCDM based distance approach. Sol. Energy 2014, 110, 519-532.

187. Vafaeipour, M.; Hashemkhani Zolfani, S.; Morshed Varzandeh, M.H.; Derakhti, A.; Keshavarz Eshkalag, M. Assessment of regions priority for implementation of solar projects in Iran: New application of a hybrid multi-criteria decision making approach. Energy Convers. Manag. 2014, 86, 653-663.

188. Ren, J.; Sovacool, B.K. Prioritizing low-carbon energy sources to enhance China's energy security. Energy Convers. Manag. 2015, 92, 129-136.

189. Ren, H.; Gao, W.; Zhou, W.; Nakagami, K.I. Multi-criteria evaluation for the optimal adoption of distributed residential energy systems in Japan. Energy Policy 2009, 37, 5484-5493.

190. Chung, E.-S.; Lee, K.S. Prioritization of water management for sustainability using hydrologic simulation model and multicriteria decision making techniques. J. Environ. Manag. 2009, 90, 1502-1511.

191. Kaya, T.; Kahraman, C. Multicriteria renewable energy planning using an integrated fuzzy VIKOR \& AHP methodology: The case of Istanbul. Energy 2010, 35, 2517-2527. 
192. Yeh, T.-M.; Huang, Y.-L. Factors in determining wind farm location: Integrating GQM, fuzzy DEMATEL, and ANP. Renew. Energy 2014, 66, 159-169.

193. Georgiou, D.; Mohammed, E.S.; Rozakis, S. Multi-criteria decision making on the energy supply configuration of autonomous desalination units. Renew. Energy 2015, 75, 459-467.

(C) 2015 by the authors; licensee MDPI, Basel, Switzerland. This article is an open access article distributed under the terms and conditions of the Creative Commons Attribution license (http://creativecommons.org/licenses/by/4.0/). 